\title{
From Nucleotides to Satellite Imagery: Approaches to Identify and Manage the Invasive Pathogen Xylella fastidiosa and Its Insect Vectors in Europe
}

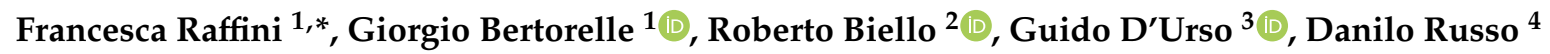 \\ and Luciano Bosso $4, *$ (D) \\ 1 Department of Life Sciences and Biotechnology, University of Ferrara, via Borsari 46, 44121 Ferrara, Italy; \\ ggb@unife.it \\ 2 Department of Crop Genetics, John Innes Centre, Norwich Research Park, Norwich NR4 7UH, UK; \\ Roberto.Biello@jic.ac.uk \\ 3 Dipartimento di Agraria, Università degli Studi di Napoli Federico II, Via Università n. 100, 80055 Portici, \\ Napoli, Italy; durso@unina.it \\ 4 Wildlife Research Unit, Dipartimento di Agraria, Università degli Studi di Napoli Federico II, Via Università \\ n. 100, 80055 Portici, Napoli, Italy; danrusso@unina.it \\ * Correspondence: francesca.raffini@unife.it (F.R.); luciano.bosso@unina.it (L.B.)
}

Received: 15 April 2020; Accepted: 28 May 2020; Published: 2 June 2020

\begin{abstract}
Biological invasions represent some of the most severe threats to local communities and ecosystems. Among invasive species, the vector-borne pathogen Xylella fastidiosa is responsible for a wide variety of plant diseases and has profound environmental, social and economic impacts. Once restricted to the Americas, it has recently invaded Europe, where multiple dramatic outbreaks have highlighted critical challenges for its management. Here, we review the most recent advances on the identification, distribution and management of $X$. fastidios $a$ and its insect vectors in Europe through genetic and spatial ecology methodologies. We underline the most important theoretical and technological gaps that remain to be bridged. Challenges and future research directions are discussed in the light of improving our understanding of this invasive species, its vectors and host-pathogen interactions. We highlight the need of including different, complimentary outlooks in integrated frameworks to substantially improve our knowledge on invasive processes and optimize resources allocation. We provide an overview of genetic, spatial ecology and integrated approaches that will aid successful and sustainable management of one of the most dangerous threats to European agriculture and ecosystems.
\end{abstract}

Keywords: ecological niche model; epidemiology; genetic diversity; genomic; GIS; insect vector; remote sensing; spatially explicit model; whole genome sequencing; Xylella fastidiosa

\section{Introduction}

Biological invasions represent one of the most severe threats to local communities and ecosystems [1]. Invasions occur when species are intentionally or accidentally introduced from the native or historic range into a new area, spread in the novel environment successfully and adversely affect it [2]. The economic loss linked to this phenomenon is conspicuous: a potential estimate of the known losses due to alien species in Asia, Australia, Europe and North America is several billion dollars per year [3,4]. Even more prominent are the ecological and social impacts of alien organisms on native species and ecosystems, which include reduced biodiversity, decreased availability and quality of key natural resources, increased frequency of wildfires, flooding and pollution [5]. 
Invasive plants and animals have been a traditional focus of research and management efforts [2,6]; however, invasive microorganisms also represent a serious threat, as exemplified by the spread of alien pathogens inducing human, animals or plants diseases [7,8]. Microbial invasions in terrestrial ecosystems are spreading exceptionally rapidly due to unprecedented migrations of organisms following anthropogenic activities and climate change [7,8]. Several of them are pathogenic and impact communities and/or environments adversely [7-9], as recently highlighted by several epidemic coronavirus [10]. Pathogens linked to emerging infective diseases of plants harm primary economic resources [11]. One of the most dangerous plant pathogens is the bacterium Xylella fastidiosa (hereafter $\mathrm{Xf}$ ) [12], which is responsible for a wide variety of diseases and has profound environmental, agricultural and economic impacts $[13,14]$.

$\mathrm{Xf}$ is a Gram-negative bacterium that colonizes the plant xylem. Taxonomically, it is a single species but it is further categorized into subspecies and strains differing in genetic diversity, geographic distribution and host specialization ([15], details in Section 2.2). $X f$ is the causal agent of many severe diseases in a wide range of wild plants and economically relevant agricultural crops; additionally, several other plants host this pathogen asymptomatically (ca. 350 plant host species [16]). Infected plants greatly vary in disease manifestation, timing of appearance and severity; a crucial role is played by host-pathogen interactions, whose mechanisms are still unclear [17]. In asymptomatic plant hosts, $X f$ lives in free-ranging small colonies in xylem vessels. Pathogenicity occurs when the bacterium rapidly multiplies locally forming biofilm clusters and compromises water and nutrients transport, leading to plant quick decline $[17,18]$.

Once restricted to the Americas, $X f$ reached Europe in 2013, infecting the Apulian olive trees (southern Italy [19]). Later, the pest was identified in several plant species in France in 2015, Spain in 2016, Tuscany (central Italy) in 2018 and Portugal in 2019 [13]. Xf was also isolated in infected plants imported to Germany and the Netherlands from South America but it was quickly eradicated [15]. Following the European outbreak, $X f$ was initially assigned to the quarantine status in the European and Mediterranean Plant Protection Organization (EPPO) A1 list (pest absent in the EPPO region) and then transferred to the A2 List (locally present in the EPPO region) in September 2017 [20].

The long-range introduction of $X f$ in Europe, likely originating from Costa Rica, is linked to anthropogenic activities, particularly commercial trade of asymptomatic infected plant material (discussed in Section 2.2, Figure 1 [21]).

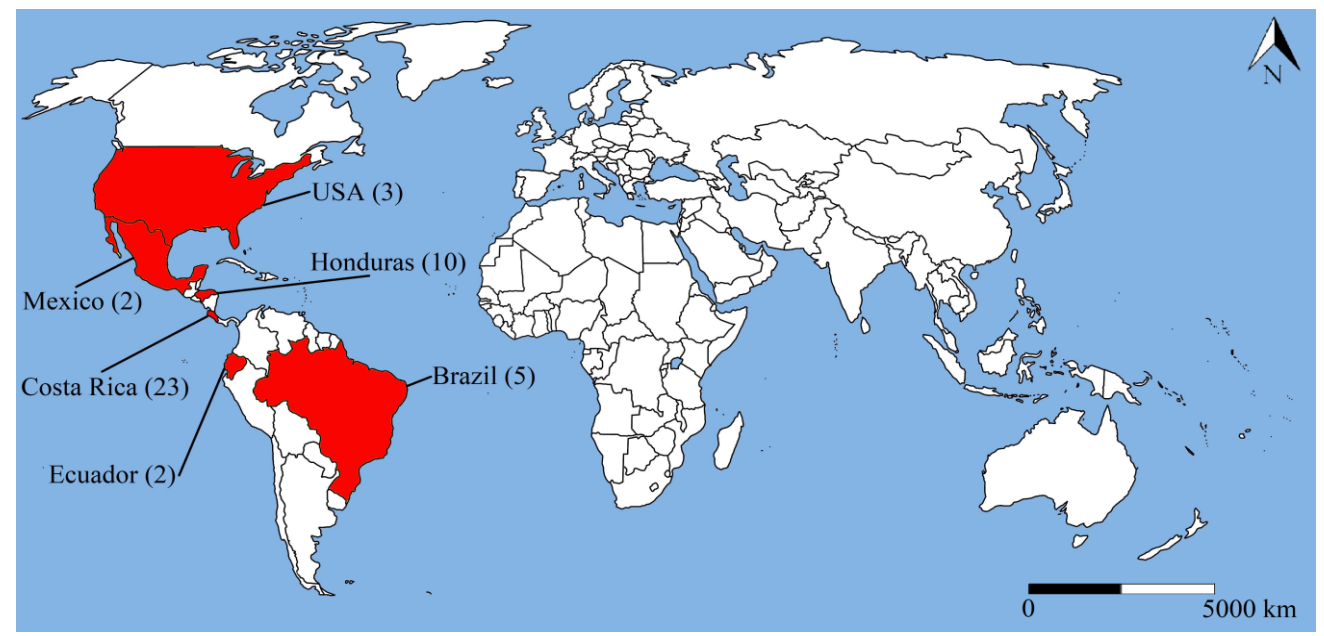

Figure 1. Country of origin (red) and number of Xylella fastidiosa infected plants imported in Europe.

However, $X f$ is a vector-borne bacterium that colonizes both plant xylem and insect gut: the small-scale spread of this bacterium among local plants is hence facilitated by xylem-sap feeding insects. Infection occurs when an insect feeds on an infected plant and subsequently on a healthy plant [22]. Insects that ingest primarily xylem sap belong to four families within the 
Hemiptera: Cicadellidae (subfamily Cicadellinae, sharpshooter leafhoppers), Cercopidae (spittlebugs), Machaerotidae (tube-building spittlebugs) and Cicadidae (cicadas) [23]. In North and South America, primary insect vectors all belong to the Hemiptera order and include the Proconiini and Cicadellini insects and spittlebugs (Cercopidae) but other xylem-feeding bugs are also suspected to transmit the bacterium with the exception of cicadas [24-26]. In Europe, spittlebugs are the dominant group of potential $X f$ vectors $[25,26]$. They have been long known to transmit $X f$, but only few studies have specifically addressed their active role in pathogen spread [27-30].

In the Apulian olive orchards, the $X f$ insect host is the meadow spittlebug Philaenus spumarius (Linnaeus, 1758) (Hemiptera: Aphrophoridae) [30-32], whose success in spreading Xf is based on its diet including a wide array of plant species, a long-life cycle and its abundance and invasiveness. Recently, other two species, Philaenus italosignus (Drosopoulos and Remane, 2000) (Hemiptera: Aphrophoridae) and Neophilaenus campestris (Fallén, 1805) (Hemiptera: Aphrophoridae), have also been confirmed to be vectors of $X f$ subsp. pauca ST53 to olive plants in Italy but only under experimental conditions [33]. Other co-occurring Hemiptera, such as Euscelis lineolatus (Brullé, 1832) (Hemiptera: Cicadellidae) and Cicada orni (Linnaeus, 1758) (Hemiptera: Cicadidae), are suspected to contribute to the spreading of this bacterium but genetic screenings (see Section 2.3) were negative and their impact is potentially more limited due to their restricted host range and seasonal or geographic constraints [22,23,25,34]. In the light of this unclear information, the current recommendation is to consider all spittlebugs as potential vectors until proven otherwise $[22,23,34,35]$. Clarifying the agents and routes of infection urgently needs further investigation [36].

No effective treatment to eradicate $X f$ is available thus far. Some chemical and biological control measures may temporarily reduce disease severity, as well as through insect vector control, but they may not be successful in eradicating $X f$ completely [37,38]. Therefore, prevention and containment are the most appropriate strategies to minimize the impact of $X f$ outbreaks in Europe. These policies are primarily based on accurate surveillance, followed by the eradication of potential Xf sources and the control of its insect vectors [39]. All these measures require a detailed knowledge of the biology, ecology and spatial distribution of $X f$ and its hosts.

Here, we aim to provide practical toolkit to scientists, stakeholders, policymakers and citizens to efficiently deal with such a threatening pathogen. We review the most recent advances on the identification, distribution and management of $X f$ and its insect vectors in Europe through genetic and spatial ecology methodologies (Figure 2).

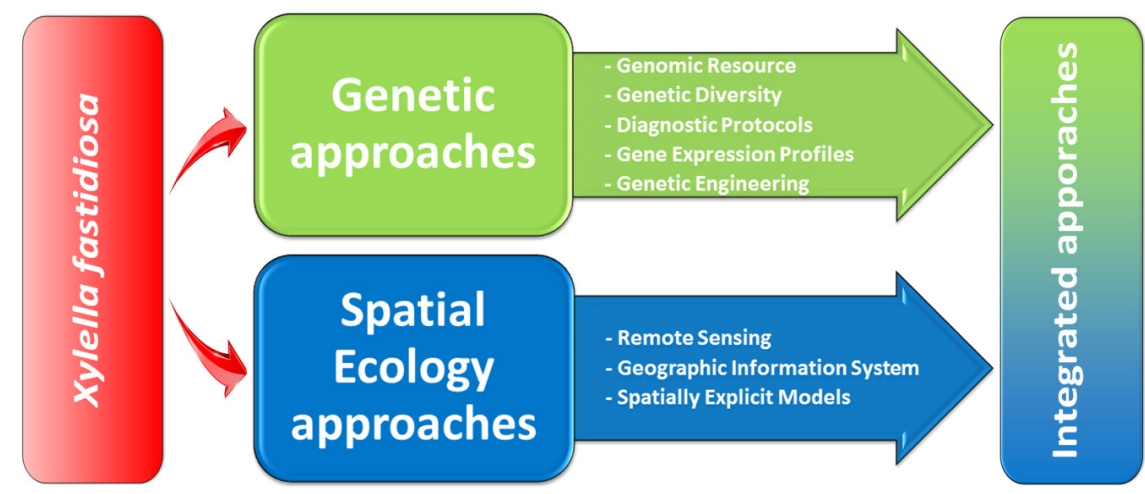

Figure 2. Overview of the genetic and spatial ecology approaches discussed in the main text in the light of their role in the identification and management of Xylella fastidiosa, particularly when combined in integrated studies.

Many studies have clarified the biology of $X f$ and its insect vectors but advances to successfully control them possibly without invasive procedures have been limited [16,23]. Latest developments in genetics and spatial ecology have proven to be markedly useful in the identification and management of invasive species, particularly through an integrated approach [40,41], which is currently largely missing 
in the $X f$ research. It is clear that a detailed and inclusive insight into ecological and evolutionary dynamics at multiple levels of biodiversity is crucial to identify, predict and prevent the spread of threatening organisms [42-44]. We discuss how genomic-scale methods would enhance ecological studies (and vice versa) of this and other invasive species and highlight promising directions worth exploring. To our knowledge, this is the first study to integrate genetic as well as ecological concepts and methodologies for this invasive bacterium. We conclude by providing indications on how to gain a comprehensive understanding of Xf, plants, insect vectors and host-pathogen interactions and aid a successful and sustainable management of one of the most dangerous threats to the European agriculture.

\section{Genetic Approaches}

Genetic applications are able to illuminate diversity, demography, ecology, adaptive potential and impact of invasive species; this essential information may not be accessible through other methods [45]. Despite the increase of theoretical and empirical research on invasive species in the last years, the genetic basis and evolutionary implications of biological invasions remain poorly understood [46-48]. The advent of the "omics" era is facilitating the application of genetic approaches for conservation and management purposes, for example by enabling a rapid discovery and taxonomic classification of alien species or tracking invasion routes [49-51]. Additionally, they provide powerful tools for the control of invasive species [52-55] and could help manage Xf and its insect vectors, as discussed in the following sections.

\subsection{Sequencing Data}

Due to the economic and ecological importance of $X f$, draft and complete genomic resources have been available since the species' proper classification in 1987 [12]. As to March 2020, 31 assemblies (Box 1) for the European strains of this species have been released in the National Centre for Biotechnology Information (NCBI) genome database (Table 1 and Table S1). Additionally, a comparative genomic database with manually curated annotations of six strains is available (Table 1): none of these six genomes is European but they provide a valuable source for comparative studies.

Table 1. Xylella fastidiosa genomic databases (details in the main text).

\begin{tabular}{ccc}
\hline Region & Source & Link \\
\hline Brazil/USA & Xf Comparative Genome Database & https://www.xylella.lncc.br \\
Europe & XF-ACTORS & https://www.xfactorsproject.eu/project/genome- \\
UK & sequences-of-eu-strains-of-xylella-fastidiosa/ \\
UK & SapFeedersHub & https://www.jic.ac.uk/brigit \\
Worldwide & Xf MLST Database & http://sapfeedershub.jic.ac.uk/ \\
Worldwide & CBOL & https://pubmlst.org/xfastidiosa/ \\
Worldwide & NCBI & https://www.ncbi.nlm.nih.gov/genome/genomes/173? \\
\hline
\end{tabular}

The first and representative genome, $X f$ subspecies pauca 9a5c (citrus-specific phytopathogen from Brazil), has a total length of $2.73 \mathrm{Mb}$, includes a single circular genome and two plasmids, and has 2330 identified protein-coding genes but half of them have an unknown function ([56], NCBI, Table 1). Subspecies, including the European strains, differ in genomic structure, content and diversity (Table 1, NCBI, Table S1). Only 900 genes are shared among the Xf subspecies pauca, fastidiosa and multiplex (core genomes, Box 1) while their accessory genomes (Box 1) are conspicuous (ca. 1500 genes, Table S1 [57,58]).

$\mathrm{Xf}$ was the first plant pathogen to enter in the genomic era [56]. The amount of existing genomic information has markedly increased since 2013 due to the rising concern following the outbreaks in Europe and the decreasing costs of sequencing technologies (NCBI, Table 1). However, while the quality and completeness of $X f$ assemblies has improved over the years, most of them are still 
fragmented, likely due to the presence of repeated regions [59]. In Europe, only three isolates (Box 1) of a single $X f$ strain have fully assembled and circularized genomes; the great majority of available genomic information are represented by fragmented assemblies (Table S1).

Box 1. Definitions of some genetic terms used in the main text.

\begin{tabular}{|c|c|}
\hline Term & Definition \\
\hline Accessory genome & $\begin{array}{l}\text { Part of genes that are not present in all strains of a species; } \\
\text { typically includes strain specific adaptation such as } \\
\text { antibiotic resistance. }\end{array}$ \\
\hline Clade & $\begin{array}{l}\text { A group of organisms that include a common ancestor and all } \\
\text { its descendants. }\end{array}$ \\
\hline Competence & $\begin{array}{l}\text { Ability of a microorganism to incorporate exogenous DNA in } \\
\text { its genome. }\end{array}$ \\
\hline Core genome & $\begin{array}{l}\text { Part of genes that are present in all strains of a species; typically } \\
\text { includes housekeeping genes for cell envelope or } \\
\text { regulatory functions. }\end{array}$ \\
\hline Genetic vector & $\begin{array}{l}\text { Vehicles (e.g., DNA plasmids, viruses, artificial chromosomes) for } \\
\text { delivering foreign DNA into recipient cells. }\end{array}$ \\
\hline Genome assembly & $\begin{array}{l}\text { A computational representation of a genome sequence. Genomes } \\
\text { are not sequenced along the complete length of a chromosome but } \\
\text { fragmented: these fragments are sequenced and then put back } \\
\text { together (assembled). }\end{array}$ \\
\hline Epigenetic variation & $\begin{array}{l}\text { A hereditary but reversible change in gene expression not } \\
\text { involving modifications in the DNA sequence. }\end{array}$ \\
\hline Isolate & A sample or culture of microorganisms isolated for study. \\
\hline Multi-locus sequence typing (MLST) & $\begin{array}{l}\text { A standardized typing method based on Sanger sequencing of } \\
\text { seven housekeeping genes not under positive selection; each } \\
\text { allelic combination defines a Sequence Type (ST). }\end{array}$ \\
\hline Pangenome & $\begin{array}{l}\text { The entire gene set of all strains of a species, including both the } \\
\text { core and accessory genome. }\end{array}$ \\
\hline Pathogen confusion & $\begin{array}{l}\text { Alteration of the in planta levels of diffusible signaling factors that } \\
\text { regulate pathogen virulence to reduce infections. }\end{array}$ \\
\hline Plasmid & $\begin{array}{l}\text { A small, extrachromosomal DNA molecule within a cell that is } \\
\text { physically separated from chromosomal DNA and can } \\
\text { replicate independently. }\end{array}$ \\
\hline Prophage & $\begin{array}{l}\text { A bacteriophage genome that is inserted and integrated into the } \\
\text { circular bacterial DNA chromosome or exists as an } \\
\text { extrachromosomal plasmid. }\end{array}$ \\
\hline Repeated genomic regions & $\begin{array}{l}\text { Sequence patterns that occur in multiple copies throughout } \\
\text { the genome. }\end{array}$ \\
\hline Sequence type (ST) & $\begin{array}{l}\text { A group of individuals sharing the same multi-locus sequence } \\
\text { typing (MLST) profile. }\end{array}$ \\
\hline Strain & $\begin{array}{l}\text { A group of microorganisms that are genetically distinct from other } \\
\text { groups of the same species or subspecies. }\end{array}$ \\
\hline
\end{tabular}


$X f$ whole genome sequences were initially obtained using random shotgun cloning strategies and Sanger sequencing $[56,60,61]$. Later, studies took advantage of the cheaper and more efficient massively parallel short reads sequencing approaches such as Illumina platforms [62-67]. In some studies, short (Illumina) reads strategies have been complemented by long reads (PacBio, Nanopore) and single molecule real time sequencing to reduce assembling complexity $([59,64,66]$, Table S1, see $[68,69]$ for detailed reviews of sequencing technologies). A combination of long (conserved genome organization, genome closure), short (high coverage and high quality polishing) and Sanger (gap bridging) sequencing, which optimizes the advantages vs. drawbacks of these methods is typically recommended [69].

Annotation, the identification and localization of protein-coding genes and other functional regions in the genome, has been based on homology-based search tools and/or ab initio gene prediction algorithms (listed in Table S1). They all are automatic annotation pipelines, which can produce inaccurate results due to methodological inconsistencies, spelling mistakes, pseudogenes, hypothetical proteins and paralogs [70]. This likely contributed to the incomplete genomic representation of Xf; additional studies and functional assays are required for a more accurate picture on gene content and its diversity within and among subspecies [71].

Vector genomes can illuminate the genetic basis of pathogen-vector interactions, their spread and invasion routes. The genome of the meadow spittlebug $P$. spumarius, the primary vector of $X f$ in Europe, has been recently sequenced through 10× genomics linked-reads [72], a sequencing technology based on short reads that preserves long-range information. The resulting genome assembly of $2.7 \mathrm{~Gb}$ is highly fragmented, likely due to the high heterozygosity; nonetheless, it is considered complete and representative of $P$. spumarius' gene content. Efforts to generate a chromosome-level assembly for this and additional ten species of xylem-feeding insects are underway (Table S2, Roberto Biello, unpublished work).

\subsection{Genetic Diversity}

A deep understanding of genetic relationships and diversity within $X f$ is of paramount importance for the management and prevention of outbreaks. In fact, while this pathogen is known to infect a wide range of plant species, its strains (Box 1) show specialization for a limited number of hosts. Some host-pathogen genotype associations remain asymptomatic and the emergence of new diseases and host ranges is associated with genomic recombination between different strains/subspecies [73].

Various approaches have been used to explore genetic structure in $\mathrm{Xf}$ : single- or multi-locus polymorphic genetic markers and, more recently, whole genome sequencing. Genomic analyses are being facilitated by the decreasing costs of high-throughput sequencing technologies and bioinformatic tools to quickly extract information associated to a group of organisms from available genomes and efficiently explore diversity in the large Xf pangenome (Box 1 [58,74-76], Table S1, see [77] and Section 2.3 for further methodological discussion). Despite the copious efforts, a conclusive classification of $X f$ subspecies is still debated mainly due to methodological differences among studies, biased sampling limited to important crop plants and horizontal gene transfers that are favored by the natural competence of this organism [73]. According to the EPPO, three subspecies are formally recognized: $X f$ subspecies fastidiosa (main plant hosts: grapevine, almond), multiplex (stone fruits, share trees, olive, plums) and pauca (citrus, coffee, olive) [15]. Among them, only the first two are accepted by the International Society of Plant Pathology Committee on the Taxonomy of Plant Pathogenic Bacteria. Multi locus sequence typing (MLST, Box 1, discussed below), phylogenetic, genomic and ecological studies have indicated further genetic and biological diversity and the presence of other potential bacterial subspecies such as $\mathrm{Xf}$ subspecies sandyi (main plant hosts: oleander, magnolia), tashke (chitalpa) and morus (mulberry). Their relationships are not fully resolved and the same host species can be infected by various pathogen subspecies [15,31,74,76,78-85]. In Europe, four Xf subspecies have been reported since the first outbreak in 2013: fastidiosa, multiplex, pauca and sandyi (Figure $2[15,31,39,80,86-88])$. A recent phylogenomic-calibrated tree estimated a divergence time 
among subspecies between 10,000 (Xf subspecies pauca vs. Xf subspecies fastidiosa plus $X f$ subspecies multiplex) and 3400 ( $X f$ subspecies fastidiosa vs. Xf subspecies sandyi) years before present [58]. Each subspecies is under different selective pressures, contributing to their divergence $[58,89]$.

Within subspecies, additional grouping of genotypes with distinct genetic and biological features is based on MLST, a largely accepted portable and robust genetic typing method to standardize genetic analyses [90]. As March 2020, 87 ST profiles have been reported worldwide, twelve from Europe (Xf MLST database, Table 1 and Figure 3 [63,76,78,82,87,90-95]). Importantly, new STs have been described for Europe since 2013 representing hitherto undescribed genotypes, revealing that our current knowledge of this pathogen is still incomplete and/or $X f$ is rapidly evolving [96].

Although MLST revolutionized taxonomy in the face of genetic recombination, it is based on conserved genomic regions which may not have full discriminatory power. In fact, studies based on more polymorphic markers and genomic data showed a lack of ST monophyly and further genetic differentiation among subspecies and strains [66,97-99]. Differentiation is sometimes reflected in genomic rearrangements, such as the inversion that distinguishes the Apulian isolates from the Brazilian ones of the same subspecies Xf pauca [66]. Divergence among subspecies/strains/isolates is in some cases pronounced enough to question their affiliation to the same group or even species [66,97-99].

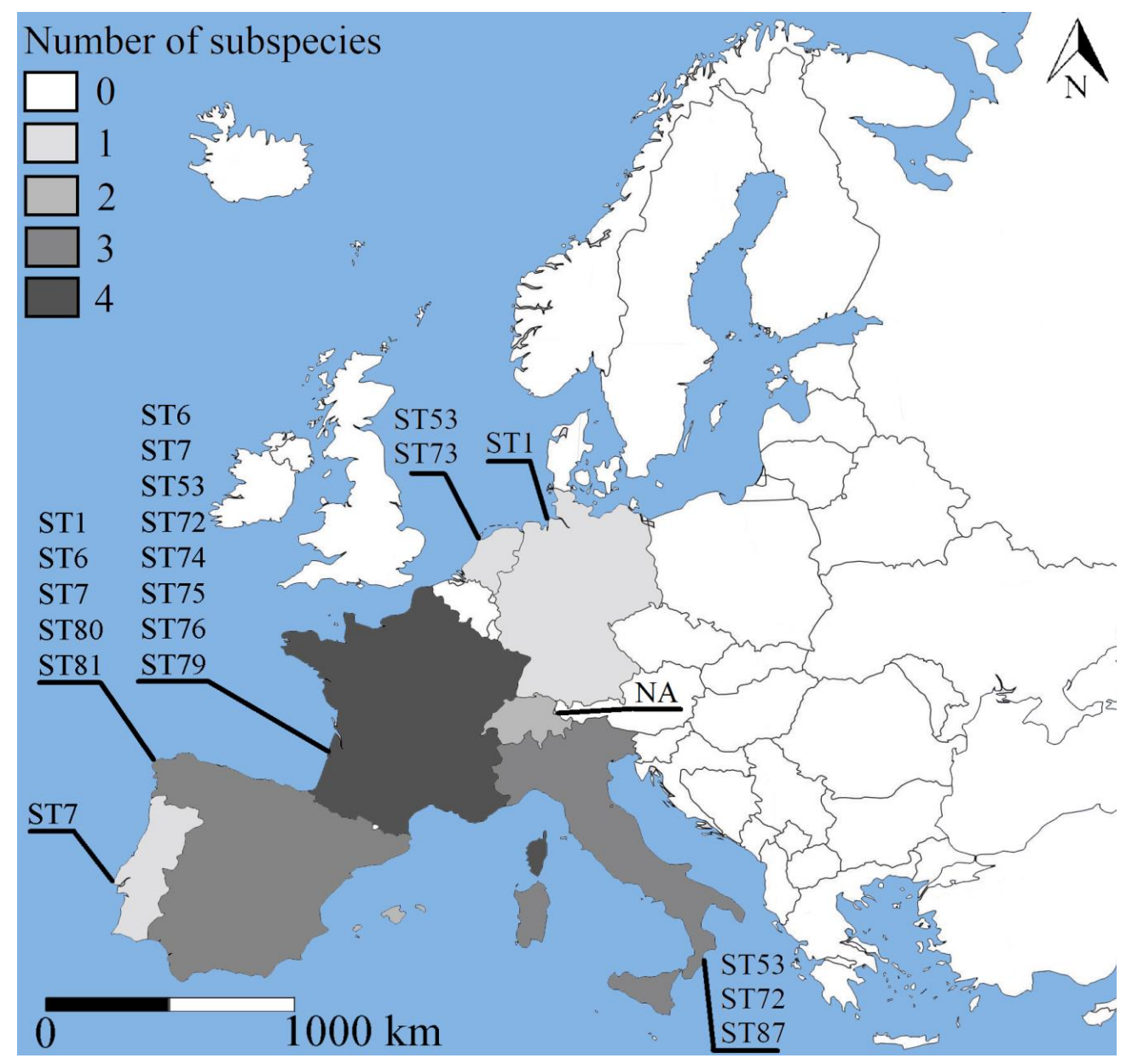

Figure 3. Number of Xylella fastidiosa subspecies and multi-locus sequence type (ST) established and/or intercepted in Europe (data from Table S1 [31,95]). Xf was intercepted in Switzerland but information on the subspecies or ST is not available. NA, Not Available.

Whole genome sequencing has provided a significantly finer resolution than other approaches, which is necessary to discriminate between different microevolutionary scenarios and routes of dispersal. The four subspecies found in Europe have originally evolved in America in allopatry: Xf 
subspecies pauca in South America, $X f$ subspecies multiplex in North America, $X f$ subspecies fastidiosa in Southern Central America and Xf subspecies sandyi in Southern USA. Then, they have dispersed repeatedly in North, Central and South America, from which they reached Europe via Costa Rica (Xf subspecies pauca and sandyi), California (Xf subspecies sandyi and fastidiosa) and the Southeastern USA ( $X f$ subspecies multiplex; Figure $1[58,62,64,66,76,82,90,94,100-105])$. The $X f$ subspecies multiplex has been introduced to Corsica multiple times but only once to Italy and Spain. The Italian $X f$ subspecies pauca infection is the result of a founder event by a single or few closely related lineages in $2008[58,66,106]$. Anthropogenic activities, particularly commercial trade of asymptomatic infected plant material, are the main vector of introduction of $\mathrm{Xf}$ in Europe (Figure 1 [80]).

$\mathrm{Xf}$ exhibits high genomic variability and plasticity, allowing for a high adaptive potential $[58,59,104,105,107-109]$. Host adaptation in this pathogen is mainly facilitated by multiple inter- and intra-subspecific homologous recombination events that created new genotypes able to invade new ecological niches $[58,59]$. Wild-type and experimentally generated hybrids show that transformation frequency is variable among strains/subspecies and increases with the concentration of environmental calcium, the number of sympatric strains and the lineage age $[21,58,59,108,110]$. Horizontal gene transfer is well described in the American strains. In Europe, the Xf subspecies pauca ST53 seems to have acquired genes from other subspecies or different species before its introduction in this continent, while evidence of post-colonization recombination is not clear in the $X f$ subspecies multiplex and fastidiosa. Highly hybrid strains intercepted in Europe from plants imported from Central and South America include Xf subspecies pauca CFBP8072, Xf subspecies sandyi XFC033 and $X f$ subspecies fastidiosa CFBP8073 [21,58,59,102]. Interestingly, all subspecies experienced recent intersubspecific recombination at common loci that are important to colonize the host environment [59] and some European strains show recombination with uncharacterized genotypes (e.g., CFPB8416 [21]).

Culture purification, genetic homology and circular contigs revealed the presence of numerous mobile elements such as plasmids and prophages (Box 1) in the Xf genome (18\% in the strain $9 \mathrm{a} 5 \mathrm{c}$ [111]). These genetic elements are differentially enriched among $X f$ strains, encode accessory modules conferring selective advantages in specific environments, may activate/inactivate host genes and facilitate horizontal gene transfers [57,112]. Although additional plasmids in $X f$ continue to be characterized, they are difficult to analyze due to their low resolution and repeated sequences (Box 1 [74,113-116]). Additionally, their role during infections is still largely unknown; in fact, only few studies have moved beyond inference from homology with integrated in vivo and in vitro analyses [57,112].

Few studies have explored genetic diversity in the European $X f$ insect vectors so far and those were limited to few loci to clarify the insect's colonization history or the genetic basis of color polymorphism [117-119]. None of these studies investigated genetic structure of these insects in the light of their role as potential Xf vectors, yet it may underlie relevant biological and epidemiological differences. The upcoming availability of numerous genomic resources (see Section 2.1) will facilitate comparative studies and illuminate the genomic basis of $X f$ infection in insect hosts.

\subsection{Diagnostic Protocols}

No treatment or control measure is currently effective to eradicate $X f$ [95]. Therefore, fast and reliable diagnostic tools for an early and accurate discovery and identification of this pathogen are crucial for successful management of current and future epidemics in Europe. Phenotypic approaches or plant symptoms have proven to be inefficient monitoring and survey tools as early stages of infection can be asymptomatic and isolation or microscopy analyses is difficult and time-consuming [31,120]. A panel of standardized diagnostic methods to monitor the presence of $X f$ infections in Europe based on serological or genetic tests is available and annually revised [15].

Serological methods based on antibodies and immunofluorescence were the first to be established but are more expensive, time-consuming and less informative than nucleotides-based approaches [15]. In particular, they are not effective in determining subspecies $[15,39,77]$. Only a limited number 
of studies applied serological protocols to the European strains, often in combination with genetic strategies [93,121-125].

Genetic methods have been the most widely used for a rapid detection of $X f$ so far. They include amplification of specific Xf genes through classic or more advanced polymerase chain reaction (PCR) approaches, single nucleotide polymorphisms (SNPs) and MLST [39,77,89,92,126]. These tests greatly vary in specificity, sensitivity, accuracy, flexibility, portability to the field and costs in terms of time, skilled labor and money; the choice of the most effective diagnostic technique largely depends on aims (e.g., quick pathogen detection vs. precise subspecies identification) and hosts [15,39,77,126-129]. MLST is a classification and diagnostic scheme that is strongly recommended in the case of new outbreaks but is not effective for large-scale screenings and to discriminate among closely-related lineages $[63,76,82,87,90-94,98]$. To this aim, SNPs provides deeper resolution, but their discovery is heavily based on an appropriate reference genome(s) and results from different studies might not be comparable [68]. Developing faster, more reliable and efficient genetic tools that allow the simultaneous detection of $X f$ and its identification at the subspecies/strain level as well as the detection of mixed infections of multiple subspecies in one sample has been the focus of the most recent assays [91,129-131]. Other efforts have aimed to portability, low-cost and ease of use with the development of miniaturized devices such as lab-on-chip, which shows intermediate performance between ELISA and RT-PCR methods [132].

The genetic methods used to diagnose $X f$ are based on a limited set of loci, require prior knowledge of the analyzed sequences and are prone to false-positive and false-negative results [77,128]. Importantly, they are mainly restricted to regions of the genome that are present in all the analyzed isolates (most likely the core genome), potentially discarding useful information from the accessory genome [116]. Multiple approaches are often required to increase diagnostic power and resolution [77,128]. Genome approaches are not yet time and cost effective for the rapid identification of pathogens and for field applications, but they allow for the quick discovery of multiple, genome-wide makers (e.g., SNPs) for strain/isolate classification and for tracing and monitoring projects [77,129]. Recently, metagenomic approaches allowed detecting and characterizing $X f$ without the need for pathogen cultivation and amplification of specific bacterial genes, but subspecies or strain classification was limited to material with high bacterial concentrations [129-132].

A recurrent issue with the above-mentioned approaches is the low concentration or uneven distribution of bacteria in host tissues, as well as the presence of metabolites that impair amplification protocols [128,131-133]. Several approaches were developed to reduce these challenges $[78,91,130,133-136]$, but they require expensive infrastructure and skilled operators. A fast and cheap alternative approach is targeting plant physiological markers involved in the early, pre-symptomatic host response to the pathogen in advanced PCRs; this method can be particularly useful in the field due to its portability $[127,137,138]$.

Genetic diagnostic protocols to identify Xf within insect vectors largely overlap with the methods developed for plants host discussed above, including MLST for subspecies classification, with some modifications to improve isolation from insects [86]. Xf multiplies in the insect foregut and does not spread to other organs. This trait facilitates $X f$ isolation within vectors [86], although bacteria may exist at low concentrations and PCR inhibitors challenge $X f$ identification $[13,139,140]$.

The classification of $X f$ infected insects is typically based on the morphological analysis of adult specimens, but genetic tools applicable to all life stages greatly facilitate the task. Standard species identification through cytochrome c oxidase I (COI) are routinely used ([141], Consortium for the Barcode of Life CBOL, Table 1). Higher discriminatory power could be reached by sequencing the region at the $3^{\prime}$ end of the COI, as well as the $12 \mathrm{~S}$ and $16 \mathrm{~S}$ genes, although there is still no evidence that these regions will allow the discrimination of cryptic insect species $[142,143]$. Recent advances in the mitochondrial genome sequencing [144-146], long-range PCR [147], nuclear whole genome sequencing and SNPs panels will dramatically improve pests screening in the near future. 


\subsection{Gene Expression Profiles}

Gene expression is a crucial link between genotype and phenotype; its regulation plays a key role in adaptation and evolution. Transcriptomic studies in $X f$ and plants under different conditions contributed to shed light on this pathogen and the processes underlying host-bacteria interaction and disease emergence.

Gene expression profiling of $X f$, together with genomic comparisons and mutagenesis (see Section 2.5), clarified the genetic basis and mechanisms of colonization and pathogenicity, although several processes remain elusive largely due to uncharacterized or nonexclusive genetic elements $[17,56,106]$. Hybridization-based microarray, quantitative PCR (qPCR) and RNAseq studies revealed that differences in genomic sequences between strains are reflected and amplified in gene expression, with a conserved core gene pool linked to survival in plant xylem and a flexible set including genes that favors adaptation in different hosts and putative pathogenicity factors: $X f$ plastically adapts its survival strategy to the environment [111,148-152]. They also showed that plasmids and prophages are transcriptionally active and modulated independently from the rest of the genome $[111,149]$.

Transcription control is environment-dependent and it should therefore be analyzed in vivo or in conditions that closely resemble natural settings to meaningfully represent the trait under analysis. As in planta studies are technically challenging in Xf, most analyses of gene expression in this bacterium have been performed in vitro in batch cultures, but this pathogen survives only in environments under continuous flow (xylem vessels and insects' feeding canal $[17,110])$. Whole transcriptome sequencing and qPCR in microfluidic chambers, which mimics the natural habitats of this bacterium, showed that gene expression and the regulatory role of environmental elements such as calcium are different between batch and flow settings [110]. This difference should be considered for planning new transcriptome studies and for correctly interpreting previous results.

Differently from other bacterial pathogens, $X f$ lacks virulence genes and effector proteins [60]; disease induction largely depends on host-specific factors $[111,153]$. Following infection, major plant pathways are activated including genes linked to immunity, bacteria and embolism sensing, calcium metabolism and lignification [125,154-156]. The pathogen is perceived as an abiotic stress related to drought [110]; however, plant gene expression changes associated with $X f$ are clearly distinct from those associated to water stress $[157,158]$. Comparative transcriptome and physiological analyses in resistant and susceptible plants highlighted that resistance to this pathogen is linked to an advanced plant ability to quickly and effectively respond to water deficiency [138,156-159]. Additionally, some resistant plants may control $\mathrm{Xf}$ without showing dramatic alterations in genes expression of the defense cascade. In such cases, further uncharacterized genetic elements or other mechanisms such as a lower anatomical cavitation susceptibility or an ionomic composition that is protective against disease might be involved $[159,160]$.

Only a handful of the above-mentioned studies used high throughput sequencing approaches; among these, just few involved the European species and were restricted to host plants [161,162]. The application of RNAseq and its most recent developments [163] has been hampered by the cost of these sequencing technologies (now decreasing), the dilution issue when total RNA from both plant and pathogen is sequenced, the presence of repetitive regions and the low quality of most available genomes [137,152]. However, these high-throughput tools provide a more detailed and quantitative view of gene expression, alternative splicing and allele-specific expression compared to former techniques (such as microarrays), without the need of a priori knowledge on sequences [164]. It could also help uncovering gene regulatory networks, another unexplored avenue in Xf.

Gene expression profiles have been poorly analyzed in Xf insect vectors. Several studies have uncovered the genetic basis of phenotypic plasticity and adaptation of insect pests to their host plants [165-168] but none of them has focused on spittlebugs. In other herbivorous pests, transcriptomic data in caterpillars feeding on multiple plants showed two sets of highly expressed genes involved in the evolution of polyphagia [166]. In the green peach aphid Myzus persicae (Sulzer, 1776) (Hemiptera: Aphididae), the differential regulation of genes belonging to the aphid-expanded gene families underlies 
hosts plasticity [165]. Future studies on gene expression profiles in P. spumarius and other potential Xf insect vectors might help explain its wide ecological niche and its ability to transmit $X f$ to multiple plant species, with significant consequences on the development of management strategies.

\subsection{Genetic Engineering}

Exploratory genetic and genomic tools, such as the ones described in the previous sections, have significantly improved our understanding of $X f$ pathogenicity. However, complementary methods are needed to validate these findings, provide insights into the functional significance of observed variation, especially in the light of the fragmented annotation of this pathogen. Genetic toolkits such as target alteration of gene expression through mutagenesis and site-specific genetic engineering have rapidly expanded in the last years and have been widely used to study gene functions and for trait improvements [169].

$\mathrm{Xf}$ is naturally competent (Box 1 [108]) but this feature does not facilitate genetic editing of this organism [170-172]. The application of conventional techniques to modify expression patterns of specific bacterial genetic elements using transposon mutagenesis and homologous recombination (methods in [173]) has been limited by laborious protocols and the slow-growing nature of this bacterium [12,120,171,174-179]. Recent developments have optimized robustness, efficiency and time effectiveness of genetic manipulation protocols [171]. Successful studies involving comparisons of wild-type and overexpressed or knocked-out $X f$ mutants and complementation analyses have clarified the mechanisms underlying virulence or host specificity and helped characterizing the function of unknown genetic elements $[171,175,177,180-184]$. Some transgenic organisms were created for practical applications such as disease suppression, including a genetically modified Xf avirulent strain [180,185].

Host plants too have been selectively bred or engineered with genetic vectors (Box 1) containing target genes to increase their resistance to Xf infection [186-190]. Genetic engineering techniques such as transgenic approaches provide a high precision, fast and robust alternative to the laborious, lengthy and often unsuccessful breeding methods [191,192]. In Xf, ectopic expression of pathogen genes related to signal transduction or anti-apoptotic process in transgenic plants through indirect transformation techniques successfully reduced bacterial colonization and disease severity ("pathogen confusion", Box 1 [188-190]; methods reviewed in [191]). A significant decrease of disease symptoms has been obtained also by a transgene expressing an antimicrobial gene or a protein chimera with recognition and clearance domains that were specifically conveyed at the site of colonization $[186,187]$.

Genetic engineering provides an opportunity to control $\mathrm{Xf}$ insect vectors efficiently. For example, paratransgenetic approaches make insects incapable of transmitting pathogens through engineered symbiotic bacteria delivering anti-pathogenic molecules [193-196]. This approach has been successfully applied in California (USA) to block Xf infection through the glassy-winged sharpshooter Homalodisca vitripennis (Germar, 1821) (Hemiptera: Cicadellidae) and its engineered bacterial symbiont that expresses two antimicrobial peptides $[197,198]$.

All these studies focused on the non-European strains or species, which benefit from wider genetic resources and a more detailed knowledge of the mechanisms underlying infection and resistance. Thus far, only two engineered viral vectors to induce pathogen confusion have been planned for the Apulian olive tree but results have not been reported yet [199]. Genetic engineering has not been widely used in Europe also due to the stronger negative perception of genetically modified organisms and its stricter regulation [200,201]. Additionally, the success of genetic transformation techniques has been limited by illegitimate recombination, non-mendelian inheritance of transgenes, availability of few characterized genes and the quantitative nature of some trait of interest [191,192,200]. Caution must be taken when translating in vitro or in-house tests into expected patterns in the field, as recently shown by long-term studies in Xf [187]. The advent of precision breeding technology or more efficient cis-genetic tools such as engineered site-specific endonucleases (e.g., CRISP/Cas9), which edit genomes without introducing foreign genes and create non-transgenic plants, could help overcome these issues 
but potential implications (e.g., cascade effects on trophic networks and/or ecosystem functioning, legitimacy to engineer wild species, etc.) should be carefully considered [191,192,200-203].

\section{Spatial Ecology Approaches}

Spatial ecology aims to uncover the causes and consequences of organism distribution and its changes over space and time [204,205]. Special attention has been devoted to biological invasions due to their significant adverse ecological and economic effects. However, there is no single tool or unified approach to understand and predict invasion impacts [206,207]. A deep understanding of ecological and evolutionary feedbacks between invasive species and native communities can identify targets for the eradication or minimization of alien organisms in addition or in support to field surveys [207].

Spatial ecological approaches such as Remote Sensing (RS), Geographical Information Systems (GIS) and Spatially Explicit Models (SEMs) have aided a successful identification and management of invasive species, especially when these methods were combined [6,208-216]. These tools have provided crucial insights into the ecological factors influencing invasions, informed detection and surveillance of invasive species via direct or indirect indicators and predicted current or future invasion dynamics [209-212]. Most of their applications have involved alien pathogens of animals, plants and humans [208,209,213-216]. However, these tools have proven to contribute valuably to effective management strategies in several plant diseases, for example by identifying suitable areas or ecological cues that are relevant for the alien species, detecting pathogens and their vectors, assessing crop quality for indications of biotic stressors and estimating future distributions ([208,211,213,216], Sections 3.1-3.3). Among plant pathogens, researchers dealing with $X f$ have significantly benefited from spatial ecology tools first in the USA and more recently in Europe, leading to substantial improvements in the management of this concerning organism [95,217-221]. However, previous studies that examined the available knowledge and management measures on $X f$ have generally not noticed the significant contribution of spatial ecology tools. In the following sections, we fill in this gap by introducing studies that took advantage of RS, GIS and SEM techniques for the identification and management of $X f$ and its insect vectors in Europe.

\subsection{Remote Sensing}

The early detection and updated mapping of the Xf distribution is critical to limit its spread and subsequent economic and ecological losses. RS approaches aimed to detect disease symptoms in plants include multispectral, hyperspectral, airborne digital color or video imagery (Box 2 and Table S3 [222,223]). Thanks to their high sensitivity, specificity, rapidity and affordability, these tools are useful to identify infected plants and delimit epidemic areas, particularly when scarce resources were available for extensive field surveys [224].

Box 2. Definitions of some spatial ecology terms used in the main text.

\begin{tabular}{ll}
\hline $\begin{array}{l}\text { Term } \\
\text { Area Under Curve (AUC) }\end{array}$ & $\begin{array}{l}\text { Definition } \\
\text { A measurement of the discriminatory ability of classification } \\
\text { models. The closer the AUC to 1, the better the predictive ability } \\
\text { of the model. }\end{array}$ \\
Bayesian inference approach & $\begin{array}{l}\text { A method of statistical inference in which the Bayes' theorem is } \\
\text { used to update the probability for a hypothesis as more evidence } \\
\text { or information becomes available. }\end{array}$ \\
biomod2 & $\begin{array}{l}\text { An R package for ensemble forecasting of species distributions, } \\
\text { enabling the treatment of a range of methodological } \\
\text { uncertainties in models and the examination of } \\
\text { species-environment associations. }\end{array}$
\end{tabular}


Box 2. Cont.

Ensemble modeling

Hyperspectral image

Leaf Area Index (LAI)

Leaf chlorophyll content

Leaf water content

Maxent

Multispectral image

Normalized Difference Vegetation Index (NDVI)

Phenocam

Solar induced chlorophyll fluorescence (SIF)

Spectral reflectance

Thermal image

True Skill Statistics (TSS)

Vegetation index
It is a process where multiple diverse models are created to predict an outcome, either by using many different modeling algorithms or using different training datasets.

Differs from the multispectral image (Table S3) because it consists of hundreds of spectral bands of limited width.

Total area of green elements (one side) in the canopy per unit horizontal ground area $\left(\mathrm{m}^{2} / \mathrm{m}^{2}\right)$.

The amount of chlorophyll per unit leaf area.

The amount of water present in a leaf.

A software to model species niches and distributions by applying a machine-learning technique called maximum entropy modeling.

A stack of several digital images, each one corresponding to the radiation intensity measured in a specific wavelength interval (spectral band, Table S3), which has been reflected or emitted by ground surface elements, represented by the image pixels.

Commonly used index calculated as (NIR-RED)/(NIR+RED), with NIR representing the reflectance measured at the near-infrared wavelength (750-950 nm, strongly reflected by vegetation, Table S3) and RED the corresponding at the red wavelength $(620-700 \mathrm{~nm}$, absorbed by vegetation, Table S3).

A digital camera set up at a fixed location to capture time-lapse images.

The reemitted solar light in the $650-850 \mathrm{~nm}$ range (Table S3) from the chlorophyll-a pigment, which is linked to the initial steps in photosynthesis.

Generic term to express the reflecting ability of a surface at a given wavelength of the electromagnetic spectrum. The distribution of spectral reflectance along the spectrum is called "reflectance curve" which has a characteristic shape for different kinds of surfaces (i.e., water, soil, vegetation, etc.).

Digital image representing the amount of radiation emitted by a surface in the thermal infrared range (7000-13,000 nm, Table S3), which is related with the temperature of the surface itself and other characteristics (i.e., emissivity).

It compares the number of correct forecasts minus those attributable to random guessing to that of a hypothetical set of ideal forecasts. It considers both omission and commission errors and success as a result of random guessing; its values range from -1 to +1 , where +1 corresponds to perfect agreement and zero or less to a performance no better than random.

It is a spectral transformation of two or more bands designed to enhance the contribution of vegetation properties and allow reliable spatial and temporal inter-comparisons of terrestrial photosynthetic activity and canopy structural variations. 
In Xf, all RS studies have been limited to olive orchards in Southern Apulia thus far (Italy [225-229]). Here, plant external physiological alterations associated with $\mathrm{Xf}$ infections (e.g., canopy defoliation, leaf wilting and chlorosis) have been surveyed with a wide array of the state-of-the-art RS technologies based on passive and active optical imaging sensors (i.e., LIDAR, Laser Imaging Detection and Ranging) from different platforms, including satellites imagery, airplanes and drones [221,225,226]]. By analyzing differences in canopy density, damages due to biotic and abiotic stresses can be generally identified by means of indices such as the Normalized Difference Vegetation Index (Box 2 [230,231]. These methods are based on conspicuous alterations in physiological structure and functions of plants but they have not been used to survey insect vectors, which do not visibly affect plants health.

Host plants presenting conspicuous stress indicators (leaf browning, wilting, chlorosis and desiccation) can be discriminated by Sentinel-2 satellites through spectral shifts [221,225,226,232,233]. This satellite imagery has been widely used to support analysis of land use and relevant geophysical variables (e.g., leaf area index, leaf chlorophyll content and leaf water content, Box 2). Compared to other satellite imaging methods (e.g., Landsat or MODIS), Sentinel-2 reports variations in vegetation characteristics with higher accuracy and narrower temporal intervals [234]. and allowed to monitor the spread of $X f$ in olive orchards at unprecedented resolution $[225,226]$. Such satellite-based monitoring has significantly supported $X f$ surveillance across large areas and informed management decisions [224]. However, satellites may detect $X f$ infections only in presence of pronounced symptoms [221,235]. Subtle variations in foliage composition and color are better identified by high-resolution airborne hyperspectral and thermal images (Box 2 and Table S3), which currently represent the best techniques to detect the early symptoms of $X f$ infection in plants [221].

Thermal anomalies occur earlier than foliage damages in density and chlorophyll content, but the required spatial and spectral resolution (wavelength range 7-12 $\mu \mathrm{m}$, Table S3) is obtained only through airborne sensors [221,228]. A promising alternative could be the emerging Unmanned Aircraft Systems, which allows for cheaper and improved resolution mapping [236]. This method would enable a wider application of RS approaches, as recently shown in Italy $[221,227]$. This approach can be transferred to other regions dealing with $\mathrm{Xf}$ outbreaks.

It is worth mentioning proximal sensing by means of LIDAR sensor, which has been used to examine asymptomatic and symptomatic olive trees through field robots [228]. While this approach could not capture Xf presence successfully [228], the use of low-cost field robots coupled with more powerful sensors is a promising approach to inspect large areas continuously.

Advanced physiology-focused RS methods are critical in supporting large-scale $X f$ surveillance and inform management efforts [225,226,237]. For example, hyperspectral observations of the top of canopies at very fine spectral resolution (Table S3) by advanced airborne sensors (e.g., FLEX and "HyPlant" [238]) may detect variations in vegetation fluorescence (Box 2 [237-239]). This signal could be used to rapidly screen large areas and monitor $X f$ infections.

Finally, a detailed testing of RS applications to Xf in a wide array of environmental settings (e.g., managed or unmanaged orchards, soil type and morphology and environmental variables) and disease symptoms in different hosts is currently unreported. Then, advanced airborne sensors, integrated approaches and multivariate models including structural, spatial and spectral data are crucial for an early and effective identification of plants infected by $X f$.

\subsection{Geographic Information Systems}

GIS tools store and analyze spatial information obtained from RS and field surveys in easily accessible databases, which have been widely used for the early and rapid assessment of $X f$ and its insect vector. Geo-referenced occurrences of $X f$ and/or its insect vectors combined with environmental variables have led to fine-scale maps that make it possible to identify the relevant abiotic and biotic factors underlying their presence and spread, predict invasion risks and estimate their epidemic dynamics to aid future surveillance campaigns. The first and currently most complete GIS database is provided by the Apulia region in a webGIS platform (SIT.Puglia, Table 2). 
Table 2. Databases including presence records and/or spatial distribution of Xylella fastidiosa and its insect vectors (details in the main text).

\begin{tabular}{|c|c|c|c|}
\hline Region & Source & Available data & Link \\
\hline Europe & EFSA & GPS coordinates, taxonomic & https: \\
\hline Europe & EUROPHYT & $\begin{array}{c}\text { classification } \\
\text { Exporting country, commodity, plant } \\
\text { species, harmful organism, number } \\
\text { of intercepts }\end{array}$ & $\begin{array}{c}\text { //www.efsa.europa.eu/en/microstrategy/xylella } \\
\text { https://ec.europa.eu/food/plant/plant_health_ } \\
\text { biosecurity/europhyt_en }\end{array}$ \\
\hline Europe & EPPO & Country, state, invasion status & https://gd.eppo.int/taxon/XYLEFA/distribution \\
\hline France & ANSES & $\begin{array}{l}\text { Country, region, municipality, } \\
\text { taxonomic classification }\end{array}$ & https://shiny-public.anses.fr/Xylella_fastidiosa/ \\
\hline Italy & SIT.Puglia & $\begin{array}{l}\text { GPS coordinates, taxonomic } \\
\text { classification, genetic test results of } \\
\text { screened plants and insects }\end{array}$ & $\begin{array}{c}\text { https://sit.puglia.it/portal/portale_gestione_ } \\
\text { agricoltura/Cartografie }\end{array}$ \\
\hline Spain & MAPA & $\begin{array}{l}\text { GPS coordinates, plant host, } \\
\text { taxonomic classification }\end{array}$ & $\begin{array}{l}\text { https://www.mapa.gob.es/es/agricultura/temas/ } \\
\text { sanidad-vegetal/xylella-fastidiosa/ }\end{array}$ \\
\hline Spain & GOIB & $\begin{array}{l}\text { GPS coordinates, plant host, } \\
\text { taxonomic classification }\end{array}$ & $\begin{array}{c}\text { https://www.caib.es/sites/sanitatvegetal/es/inicio- } \\
1542 / ? \text { campa =yes }\end{array}$ \\
\hline Worldwide & GBIF & $\begin{array}{l}\text { GPS coordinates, taxonomic } \\
\text { classification }\end{array}$ & https://www.gbif.org/species/3222355 \\
\hline
\end{tabular}

This information is linked to a high-resolution digital map (orthophotos of $50 \mathrm{~cm}$ pixels) based on a soil usage, which, as to March 2020, is divided in three management areas: infected, containment and buffer zone (http://webapps.sit.puglia.it/freewebapps/DatiFasceXF/index.html).

Similarly, the French national database stores information collected during 2015-2019 in the south of France and Corsica ([240,241], Agence nationale de sécurité sanitaire de l'alimentation, de l'environnement et du travail, ANSES; Table 2). Spain too has developed a national catalogue of Xf occurrences (Ministerio de Agricultura, Pesca y Alimentación, MAPA; Govern Illes Balears, GOIB; Table 2). Beyond the national borders, European and world databases of $X f$ georeferenced records are available from several authorities ([242], European Food Safety Authority (EFSA), EPPO and Global Biodiversity Information Facility (GBIF), Table 2).

Numerous studies have benefited from this valuable GIS information to investigate the current and future distribution of $X f$ and its insect vectors [211,243-246] (discussed in Section 3.3). However, not all national databases are freely accessible (e.g., the French database, Table 2). This barrier to data sharing strongly limits our ability to respond to rising biological invasions, particularly for highly threatening alien species that require immediate quarantine measures such as $X f$ [247]. A rapid dissemination of any invaders' information is key to deal with these extremely successful invasive pathogens. We highlight the need to move urgently beyond restricted data access to prevent efficiently further Xf outbreaks.

While RS and SEM approaches have been predominantly focused on $X f$ distribution, GIS studies mostly included $X f$ insect vectors, particularly P. spumarius $[248,249]$. Although methods to estimate abundance and the olive growth-related distribution of $P$. spumarius are based on a sweep net technique $[250,251]$, new GIS approaches can be used to monitor $X f$ insect vectors at multiple time and spatial scales [248]. Integrated field surveys and GIS data indicated that P. spumarius prefers wild herbaceous plants and switches to olive trees only at an advanced developmental stage and when the summer season progresses and herbaceous plants dry out $[248,249]$. Agricultural landscape mosaics can drive the spatial distribution and activity of this spittlebug and influence local Xf outbreaks [249]. In particular, the presence of suitable habitats such as herbaceous and shrub plants nearby olive orchards can enhance the emergence and persistence of $X f$ infections [244].

Land-use/land-cover analysis and GIS applications analyzed the landscape transformation following Xf outbreaks which resulted in compromised agroecosystems, land abandonment and reduced ecosystem services ([252], further details at https://land.copernicus.eu/pan-european/corineland-cover). To avoid these critical issues, GIS tools can assist the management of $X f$ infected areas not 
only in agricultural terms but also considering landscape and urban areas, for example to limit the spread of Xf vectors [253].

GIS approaches enable retrospective analyses to clarify the natural and anthropic factors affecting invasive species and guide the management of future outbreaks [252]. The integration of additional environmental variables (e.g., slope, altimetry and level and kind of management) would further aid the management of $X f$ and its insect vectors, for example by identifying habitat features facilitating insects' movements across agricultural landscapes. However, this kind of GIS analyses in Xf and its insect vectors have been limited to Italy $[248,252]$ while this bacterium is threatening many other countries in Europe.

\subsection{Spatially Explicit Models}

SEMs investigate the impact of factors such as biotic and abiotic variables on spatial ecological processes (e.g., species distribution, dispersal and extinction) and assess the potential response of organisms to these factors [254]. Since the $X f$ emergence in southern Italy, several SEM studies have estimated the current and future distributions, abundance and population dynamics of $X f$ and its insect vectors in Europe, mostly taking advantage of correlative and mechanistic models [214].

Ecological niche models (ENMs) are statistical frameworks that link the geographical distribution of species (georeferenced presence records; e.g., individual locations and species' presence) to spatial variation in environmental conditions (geographic layers of environmental information; e.g., climate, land cover and soil attributes), identify the factors that enable species presence and predict potentially suitable areas [255]. ENMs estimate fundamental niches of species, and are applied when the aim is to know the potential distribution, as in the case of invasive species or projections in space and time. In European ENMs studies of $X f$, presence records were obtained from online databases (Table 2) and published data [98], sources of carefully verified information that is available thanks to collaborations between researchers and farmers. Environmental predictors were selected through statistical methods $[13,14,86,219,220,240,243,256,257]$. The most widely used predictors include elevation (WorldClim and European Environment Agency (EEA), Table 3), land cover/land use (Copernicus, ESA, Table 3) and climatic variables (WorldClim and Climatologies at High resolution for the Earth's Land Surface Areas (CHELSA), Table 3) used at an equatorial resolution of ca.

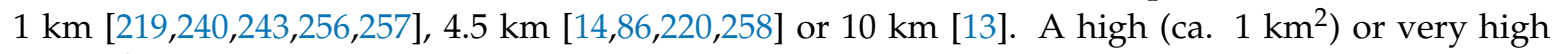
$\left(<1 \mathrm{~km}^{2}\right)$ resolution should be preferred due to $X f^{\prime}$ s small spatial range, particularly in the early stages of spread.

Table 3. The most frequently used predictors in the European Xylella fastidiosa and its insect vectors spatial ecology studies (details in the main text).

\begin{tabular}{|c|c|c|}
\hline Predictor & Source & Link \\
\hline Climate & WorldClim & $\begin{array}{l}\text { https://www.worldclim.org/data/ } \\
\text { worldclim21.html }\end{array}$ \\
\hline Climate & CHELSA & https://chelsa-climate.org/ \\
\hline Elevation & EEA & $\begin{array}{l}\text { https://www.eea.europa.eu/data-and-maps/ } \\
\text { data/digital-elevation-model-of-europe }\end{array}$ \\
\hline Elevation & WorldClim & $\begin{array}{c}\text { https://www.worldclim.org/data/ } \\
\text { worldclim21.html }\end{array}$ \\
\hline Land cover & Copernicus & $\begin{array}{l}\text { https://land.copernicus.eu/pan-european/ } \\
\text { corine-land-cover }\end{array}$ \\
\hline Land cover & ESA & http://maps.elie.ucl.ac.be/CCI/viewer \\
\hline
\end{tabular}

Similar to other invasive species [9], the potential distribution of $X f$ and its insect vectors in Europe have been mainly estimated using the free software packages Maxent and biomod2 (Box $2[13,14,129,258])$. ENMs are validated through statistical analysis and field survey. For $X f$, the 
area under curve (AUC) and the true skill statistics (TSS) have been widely used but no ground validation studies have been performed in Europe thus far (Box $2[13,14,219,220,240,243,256]$ ).

According to AUC and TSS (Box 2), the most accurate modeling algorithms used in Xf studies are Maxent, Artificial Neural Networks, Generalized Additive Models and Random Forests [13,220]. More recent developments aim to improve modeling efficiency by integrating multiple algorithms (ensemble models, Box 2 [259]), as recently used in Xf in Europe [13,220,258]. However, these ENMs are reliable only if they are accompanied by a careful parameterization of each algorithm/model underlying the ensemble, a step that is often overlooked. Researchers working with ENMs need to have a comprehensive understanding of how each algorithm works and how each algorithm responds with their particular data.

ENMs analyses indicated that the main descriptors of $X f$ current distribution are the minimum temperature of the coldest month, mean temperature of the warmest quarter and precipitation seasonality $[95,219,220,240,243]$. Xf had a high probability of occurring in the European areas characterized by warm temperatures and low rainfall during summer and mild winter temperatures $[95,220]$. In line with these predictions, the minimum threshold temperature for growth of $X f$ in plants is between 12 and $18^{\circ} \mathrm{C}$ [217] and temperatures $<6^{\circ} \mathrm{C}$ seem to kill this bacterium [260]. The mean temperature of driest and warmest quarter is likely related with the ability of the bacterium to support water stress or warm conditions [240]. Overall, the coldest period (month or quarter) is the most significant variable underlying $X f$ distribution in Europe $[13,218-220,240,258]$ and worldwide [218]. More specifically, a ENM study investigated the relationship between the potential distribution of each of the three $X f$ subspecies occurring in Europe and: (i) mean temperature of driest quarter and annual mean temperature ( $X f$ subspecies fastidiosa); (ii) mean temperature of coldest quarter and mean temperature of driest quarter ( $X f$ subspecies multiplex); and (iii) minimum temperature of coldest month and mean temperature of driest quarter ( $X f$ subspecies pauca [13]). Overall, the main limiting variable is the minimum winter temperatures, with $X f$ subspecies pauca being particularly sensible to this predictor $[13,220,243]$. Xf subspecies fastidiosa showed a significant association with the mean temperature, consistently with its year-round susceptibility to warm temperatures $[13,220]$. $\mathrm{Xf}$ subspecies multiplex presented more suitable areas with warm temperatures during the dry season but is sensitive to cold temperatures in winter $[13,220]$. Finally, Xf subspecies pauca prefers warm climates with mild winters $[13,220,243]$, low elevation $(0-150 \mathrm{~m}$ a.s.l.), intensively cultivated areas with complex patterns, oak woodland and Mediterranean shrubland [219].

According to the most recent $X f$ ENMs studies, the currently established distribution of this plant pathogen in Europe (Apulia, Tuscany, French Riviera, Corsica, Alicante and Balearic Islands) is notably smaller than the extent of climatically suitable areas, which includes the Mediterranean coastal areas of Spain, Greece, Italy and France and the Atlantic coastal areas of France, Portugal and Spain $[13,219,220,240,258]$. Interestingly, the currently climatically suitable areas identified by ENMs diverge among $X f$ subspecies. The $X f$ subspecies fastidiosa presented suitable areas in the southern regions of France, Portugal and Spain, the Balearic Islands and large regions of Italy, Croatia, Greece, Cyprus, Crete and Turkey $[13,220]$. Xf subspecies multiplex showed the most extended suitable areas among the three subspecies $[13,219,220]$. In fact, with the exception of the northwestern areas, suitable climatic conditions for this species could be found in all Europe $[13,220]$. Finally, the $X f$ subspecies pauca disclosed the most restricted suitable distribution, including southern Italy, the Mediterranean coasts, Portugal, southern Spain and France $[13,14,219,220]$. These results indicate that the $X f$ subspecies multiplex could invade most of Europe while pauca and fastidiosa could be mostly restricted to the Mediterranean basin $[13,219,220]$. More recently, a ENMss analysis has focused on three Xf ST (Box 1): $\mathrm{Xf}$ subspecies fastidiosa ST1, Xf subspecies multiplex ST6 and Xf subspecies pauca ST53 [13]. While ST1 and ST53 results did not differ from the previous analyses significantly, ST6 showed a more limited potential distribution restricted to lower latitudes [13].

ENMs can also be used to predict $X f$ distributions assuming future scenarios of climate change $[219,258]$. The future distribution of the $X f$ subspecies pauca in the Mediterranean basin 
would not be affected or shift towards north $([219,258]$, LB personal obs.) while the $X f$ subspecies multiplex will expand and/or shift northward by 2050, possibly threatening several of the most economically important wine, olive and fruit producing regions of Europe ([258], LB personal obs.). A potential limit of these studies is the use of only one global circulation model while multiple ones should be included, the use of presence records from an introduced range rather than the native regions [219], a spatial resolution that is not appropriate for the study system (ca. $25 \mathrm{~km}^{2}$ ) or a limited number of validation methods to assess the performance of their models [258].

Only few modelling studies are available for the insect vector $P$. spumarius. The most relevant climatic predictors of its presence in Europe included the maximum temperature of the warmest month, the temperature annual range and the precipitation of the coldest quarter [86]. However, a recent study in the UK showed that the optimal conditions for this spittlebug are warm areas [261]. Additionally, deciduous woodland and improved grassland, the spittlebug's preferred habitats, could support large populations of the insect vector and pose the greatest risk of Xf spread [261]. Another SEM approach to analyze the $X f$ spatiotemporal distribution are the mechanistic models, in which mathematical models describe the interaction between environmental factors and functional traits of the species that affect demography and distribution [207]. These models incorporate the mechanisms of spread and are typically used for small areas at high spatial resolution $\left(<1 \mathrm{~km}^{2}\right)$. Such models are particularly useful to identify the most successful strategies to limit further pathogen spread. This approach successfully predicted Xf spread in several areas such as southern Apulia [246,262,263] and Corsica [264,265]. In Apulia, mechanistic models showed the importance of long-distance jumps in insect vectors movement, buffer zones width and the significant role of plants other than olive trees in increasing the spread rate [266]. Network analysis suggested that attempts to eradicate $X f$ from southern Italy may be pointless and that this region will provide a pathogen reservoir for further spread [246]. Therefore, the goal of management strategies in this region should be to keep $X f$ density as low as possible, primarily through control of P. spumarius and plant removal [13]. Another mechanistic model indicated that the current insect vector dispersal is less than $1 \mathrm{~km} /$ year but this is expected to increase substantially due to human activity and passive dispersal through strong winds [13]. These models can also be used to estimate the age of the infection. For example, a Susceptible-Infected-Removed (SIR) model suggested $X f$ was probably introduced in Corsica (France) much earlier than its discovery, and the pathogen may now be difficult to eradicate. Using a Bayesian inference approach (Box 2), it was in fact confirmed that Xf was introduced to South Corsica (near Ajaccio) around 1959, long before its first detection in 2015 [264]. Integrating genetic and demographic data from North Corsica and south-eastern mainland France would clarify the occurrence of multiple introductions and human-mediated long-distance dispersal. More recently, potential strategies to limit Xf infection in Apulia through insect vectors management across its entire life cycle were evaluated using SIR models [38]. A new stochastic simulation model incorporated epidemiological information and spread patterns of $X f$ subspecies pauca in olive trees in Apulia between 2013 and 2018 to explore various epidemiological, introduction routes and management scenarios [266]. This approach could be extended to other countries that are potentially suitable to this bacterium [13]. Other mechanistic studies focusing on this pathogen are still ongoing [106,267]. However, quantifiable data and measurements on its spread in Europe are scarce mainly due to differences in the bacterial strain, plant host, insect vector and environment among $X f$ infestations $[263,265,268]$. Therefore, predicting the extent of the spread as well as assessing the efficiency of management measures is extremely challenging.

All SEM studies reviewed here agree that the European climate can be particularly favorable to Xf, particularly for the subspecies fastidiosa and multiplex $[13,220]$. Caution is warranted when interpreting models projected into new zones or in future climate scenarios that are different than the calibration area. Additionally, Xf may adapt to a wide range of hosts [269] and this rapid evolution could affect future geographical distributions yet to date this information cannot be included in SEMs $[13,220,243,258]$. 


\section{Research Perspectives}

\subsection{The Impact of Climate Change}

Climate change can directly and/or indirectly affect plant pathogens and their vectors [270,271]. Likely, the modification of key abiotic factors will influence the distribution of insects, plants and pathogens in future environments. The direction of this change is less clear, as it may impact each species and their relationships differently, as seen in aphids and viruses linked to wheat [272].

Climate has a major role in the epidemiology of all the $X f$-induced diseases [16,273]. Climate change will differentially affect Europe [274]. In Southern and Central Europe, higher temperatures and reduced mean summer precipitation are expected to increase the occurrence of heat waves and droughts, leading to progressive desertification [275]. Accordingly, Xf subspecies pauca is expected not to expand its distribution being intolerant to future climatic conditions [219,258]. Instead, in Northern and Eastern Europe, precipitations and humidity are expected to increase [274]. Thus, $X f$ subspecies multiplex will probably expand its distribution to those areas [258].

Climate change will likely expand the suitable geographic range of $X f$ insect vectors, with the risk of spreading the bacterium to previously unaffected areas, i.e., Xf subspecies multiplex [258]. Hemipterans are expected to benefit from future $\mathrm{CO}_{2}$ levels but the effects on sap sucking insects are species-specific [276,277]. Some species may be positively influenced (e.g., Aphis gossypii (Glover, 1877) (Hemiptera: Aphididae); Myzus persicae; Rhopalosiphum maidis (Fitch, 1856) (Hemiptera: Aphididae); and Bemisia tabaci (Gennadius, 1889) (Hemiptera: Aleyrodidae) [277-280]), others might show a negative trend (e.g., Brevicoryne brassicae (Linnaeus, 1758) (Hemiptera: Aphididae); and Acyrthosiphon pisum (Harris, 1776) (Hemiptera: Aphididae) [277-281]) and further sap feeders are likely to be unaffected (e.g., Aphis nerii (Fonscolombe, 1841) (Hemiptera: Aphididae); Aphis oenotherae (Oestlund, 1887) (Hemiptera: Aphididae); and Aulacorthum solani (Kaltenbach, 1843) (Hemiptera: Aphididae) [277]). Overall, the spatial distribution of many insect and pest species is often limited by unsuitable climatic conditions and geographical barriers [282,283]. However, these species may be able to overcome these climatic constraints by taking advantage of artificial environments (e.g., greenhouses [284,285]), evolutionary adaptation including emergence of resistance [286] or human-mediated dispersal [287,288]. The effects of climate change on the distribution and behavior of $X f$ insect vectors in Europe is not known and it is therefore difficult to predict if their detrimental effects on global food security will increase or decrease in the future. Increased $\mathrm{CO}_{2}$ and temperature will not only impact the distribution of $X f$ and its insect vectors, but also their interactions with plants. In fact, plant biochemistry and physiology will most probably be altered and the response against pathogens weakened under the predicted future climatic conditions. Considering this factor, therefore, direct and indirect dispersal of $X f$ will likely increase [289].

\subsection{Genetic Approaches}

Genetic approaches have significantly assisted the successful identification and management of $X f$ outbreaks (as reviewed in Section 2). A major limit to their application is the absence of complete genomes and robust annotations for most $X f$ strains and the large amount of uncharacterized genetic diversity [290]. Genetic protocols may not be equally effective in distantly related lineages but need to be adapted to different strains and hosts [110,168,187,291]. Automated annotators are benefiting from expanding datasets but this technology has not been updated in the last decade and its accuracy has decreased following the accumulation of fragmented genomes [292]. Recent technological developments such as the state-of-the-art whole genome/transcriptome sequencing, upgraded algorithms addressing several assembling issues (e.g., repetitive regions [293]) and CRISPR-based editing tools offer versatile and cost-effective procedures to obtain exploratory and diagnostic genetic tools that are specifically tailored for the analyzed sample. Gene regulatory networks can be explored through RT-qPCR [294,295] and Nanopore direct full-length RNA sequencing [296]. 
However, these cutting-edges tools and vast datasets are not easily accessible to non-bioinformatician researchers. A unified open-source workflow for automated whole bacterial genome studies [297] would enable a quick and effective identification and monitoring of outbreaks also from scientists without a computational background. At the same time, it would provide a wide amount of standardized genomic data for finer analyses.

The increasing global trade of plants could lead to further spread of this pathogen in new areas or to the introduction of novel genotypes in existing populations. Due to the high recombinant ability of this organism, sympatric populations of multiple bacterial strains could hybridize and generate more niche-adapted and/or virulent recombinants, as seen in South America $[59,66,107]$. Then, it is crucial to limit the import-export of susceptible or potentially infected material and to extensively screen plants for novel pathogen introductions and hybridization. The European areas that already host multiple strains of Xf (Corsica and Baleares, Figure 4) are at the highest risk of emergence of new variants and should be closely monitored. A more detailed knowledge of the hybrid strains and the recombination potential could possibly help to develop more efficient diagnostic protocols but also to create and/or spread strains that are avirulent or have limited ability to hybridize.

Another unexplored genetic mechanism in $X f$ is epigenetic variation (Box 1), which is known to regulate virulence in bacteria. We advocate future studies to illuminate the contribution of this kind of polymorphism to $\mathrm{X} f$ evolution and pathogenicity, for example by methylation sequencing.

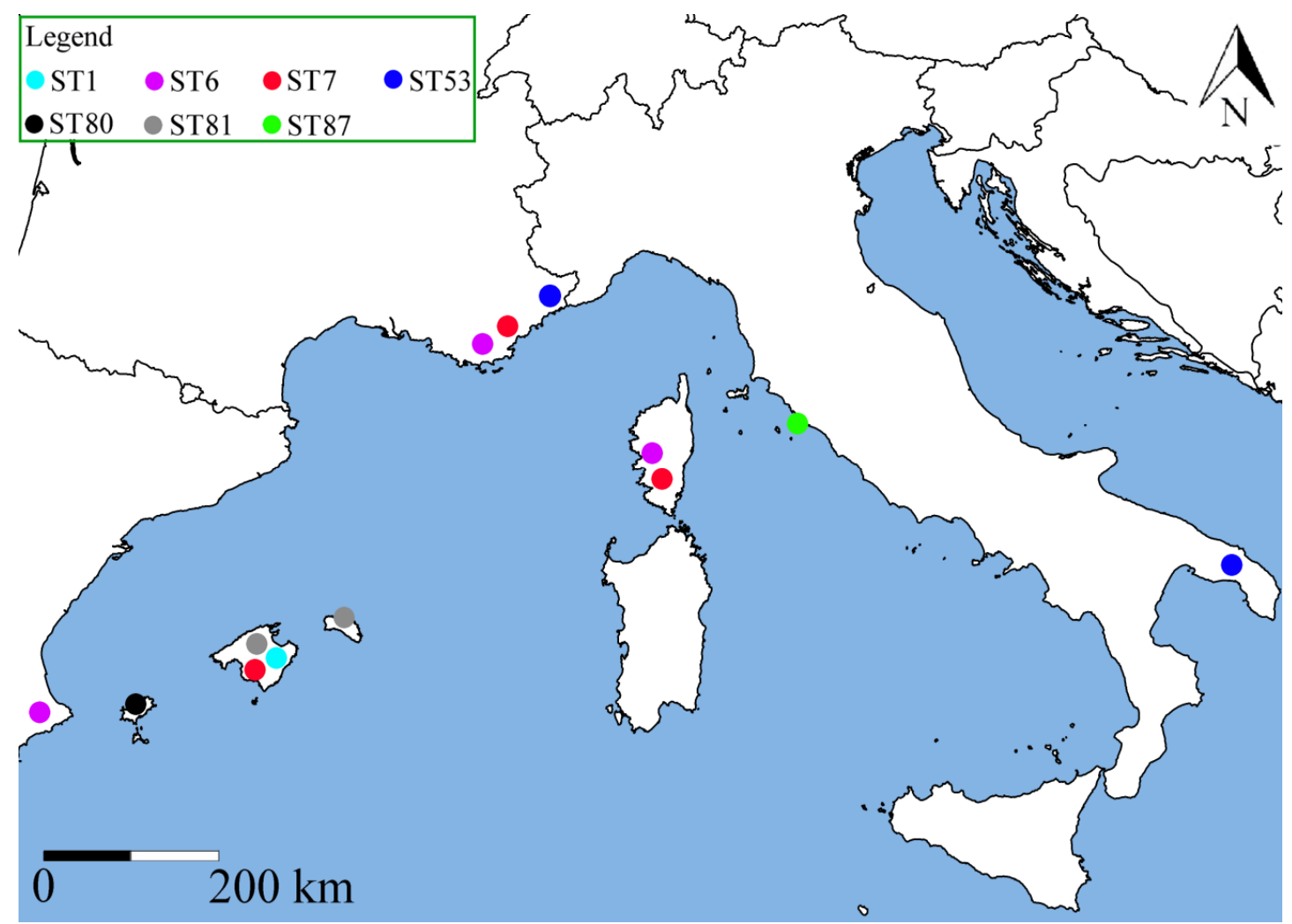

Figure 4. Spatial distribution of the European Xylella fastidiosa multi-locus sequence type (ST) that are at higher risk of hybridization due to geographical proximity or sympatry (details in the main text, data from Table S1 [32,98]).

\subsection{Spatial Ecology}

RS, GIS and SEMs methods have been rather scarcely used to investigate spatial patterns of $X f$ and its insect vectors so far, largely due to low resolution as well as difficult data accessibility and processing (as reviewed in Section 3). However, spatial ecology approaches are important tools for implementing effective management strategies. For example, they can help in obtaining a detailed 
knowledge of the biology and ecology of this pathogen and its insect vectors, identify early warning signals and optimize resources for screening [298-300].

Current hyperspectral satellite sensors (Box 2) lack the spatial resolution to distinguish individual tree foliage. $X f$ early detection would benefit from high (submeter) spatial resolution imaging spectroscopy, thermal data (Box 2) or aerial photos to assess subtle changes in spectral traits, a technology that can be potentially deployed at large scales with automated airborne platforms. Expected improvements include higher availability of multispectral optical imagery with increasing spatial, spectral and temporal resolutions, based on new satellites and sensors. Another area of development focuses on unmanned aerial vehicles and phenocams (Box 2) with increasing multispectral, hyperspectral and thermal imaging, as well as LIDAR. These tools would enable better estimates of the vegetation index (Box 2) thanks to their semiautomatic discrimination between physiological and pathological changes [301]. The resulting insights will refine our capacity to predict, detect and assess the distribution and impact of $X f$ and its insect vectors in Europe with unprecedented efficiency.

GIS developments are moving towards integrating additional territorial variables of interest (e.g., slope, altimetry, level and kind of management, insect vector distribution) and real-time geographic information [302] thanks to expanded fixed and mobile (e.g., on vehicles or pedestrians) sensor networks. More accessible data, as well as improved, free and user-friendly GIS software, are going to advance our ability to analyze $X f$ and its insect vectors, playing an important role in preventing the spread of $X f$ in Europe.

All SEM methods analyzed here could aid surveillance programs for $X f$ in Europe, for example by prioritizing areas to be inspected according to their climatic suitability. ENMs could inform the suitability of recipient areas before species are introduced and mechanistic model evaluate population changes over time according to landscapes. Future SEMs integrating insect vectors' distribution and/or population dynamics as predictors in $X f$ models as well as using several global circulation models to estimate their potential distributions in climate change scenarios (e.g., BCCCSM1-1, CCSM4, GISS-E2-R, MIROC5, HadGEM2-ES and MPI-ESMLR from WorldClim, Table 3) will likely help pursue these aims. Importantly, the early identification of invasive species is crucially based on obtaining the relevant information in a timely manner. As seen for $X f$, a clear picture of ongoing invasions is too often acquired only several years after the first report of the responsible organism. This issue partly arises from researchers relying only on well-parameterized and validated results (e.g., ENMs), a time-consuming process that can negatively affect an effective early response. To pursue this aim, preliminary models too can inform initial risk assessments [6]. SEM tools are particularly useful in screening procedures and decision-making processes related to $\mathrm{X} f$ and insect vectors management as they allow exploring, comparing and assessing the implications of different scenario in terms of likely success, cost and needed efforts before possibly implementing them.

Importantly, all the RS, GIS and SEMs methods heavily depend on data quality. Therefore, they need to be guided by a solid background on biology and ecology of $X f$ and insect vectors and by long-term research and fieldwork.

\section{Integrating Genetic and Ecological Approaches}

Multiple levels of biodiversity, from ecosystem to genetic diversity, need to be comprehensively included in studies that aim to accurately identify, understand, predict and prevent the spread of invasive species [42-44]. For example, genetic distances overlaid with environmental variables, as typical of landscape genetics studies, have illuminated current and historical movement of organisms, the underlying genetic and abiotic factors, potential colonization routes and predicted distribution shifts under future climate scenarios [43]. Additionally, maps are influential outreach instruments that are easily understood by non-experts such as citizens or conservation agencies and have greatly enhanced their understanding of the role of genetic and environmental factors on invasive species successes [43]. Then, an interdisciplinary approach combining diverse perspectives such as genetic and ecological data is one of the most powerful tools in conservation biology and epidemiology. 
Accordingly, more recent studies focusing on $X f$ seek to genetically inform spatial ecology approaches (Figure 2). The early detection of this pathogen was improved by the integration of photointerpretation of aerial/satellite images, accurate onsite data acquisition and rapid on-site pathogen detection in plant material and insect through genetic screenings [303].

Infected asymptomatic plants and insect vectors at earlier stages of infections were identified thanks to the combination of advanced PCRs, RS and SEMs leading to a highly precise spatial map of disease incidence ([86,225], methods described in Sections 2 and 3). Additionally, an undisclosed higher genetic diversity and co-occurrences of $X f$ strains were identified within insect vectors, highlighting that our knowledge of this pathogen has been largely underestimated [86]. These insects hosting multiple, sympatric bacterial populations may provide other recombination opportunities, increasing the risk of emergence of new $X f$ variants through hybridization. These studies exemplify how combining different methodologies from diverse fields lead to a more accurate and effective detection and management of Xf.

In addition to these successful first combined approaches, incorporating interdisciplinary information more closely beyond simple reciprocal corroboration can provide even more effective and thorough tools for detecting and monitoring $X f$. For example, genetic screenings alone allow identifying precisely $X f$ but are expensive in terms of both time and money (details in Section 2); spatially explicit ecological tools can delimit the area to be monitored. Inversely, environmental DNA can inform on multiple species (pathogen, plants hosts, insect vectors) distribution and abundance in a single sampling and reduce the costs associated to fieldwork and geographical imaging [42,43,304]. Transcriptomic profiling and remote sensing can supervise changes in crucial traits such as tree pigments levels in large areas at fine resolution, allowing the early identification of $X f$ infections. The distribution of genomic diversity and its association with climate maps and digital elevation models can identify adaptive variants and inform predictive modeling of host or pathogen responses to environmental factors such as climate changes [42,43,304]. These integrated models could shed light on the influence of external environment on epigenetic regulation, an information that would address a long-standing question in evolutionary biology and could help the management of this invasive species. A closer integration of $X f$ adaptive and hybridization potential as well as population size extrapolated from genomic and epigenetic data directly in the ENMs frameworks would greatly improve the prediction of outbreaks and climate responses (hybrid ENMs, e.g., [44]).

A critical limit of these integrated studies is the need of large amounts of genetic and ecological data as well as highly efficient statistical and computational resources to analyze these vast datasets and provide realistic projections. Most recent technical innovations and changes in data sharing policies are helping to affordably obtain large multidisciplinary datasets although some methodological and logistical challenges remain to be addressed [44]. Software packages that are more easily accessible to researchers from different fields would facilitate such integrations, which would be supported also by a more extensive data standardization (e.g., same resolution or format), an issue that is well known by bioinformaticians.

We advocate theoretical and empirical developments towards comprehensive interdisciplinary approaches to enable the integration of diverse perspectives that will improve our understanding of $X f$ and other invasive species and thus our ability to properly deal with this pathogen.

\section{Conclusions}

$\mathrm{Xf}$ is a highly threatening pathogen largely affecting the European agriculture. However, we are far from a comprehensive understanding of this invasive species, its hosts, ecological niches and their interactions. While previous management strategies addressing $X f$ have mainly relied on a monodisciplinary approach, we emphasize the importance of combining different perspectives such as genetic and spatial ecology and beyond. Including different, complimentary outlooks will substantially improve both our knowledge on invasive processes and resources allocation and thus significantly optimize diagnostic and management efforts. Even more imperative is an effective 
communication with stakeholders, especially those outside the academic community [305,306], to aid a successful and sustainable management of one of the most dangerous plant pathogens. This organism also offers an exceptional study system to explore the evolution of pathogenicity at different levels of biological complexity, from molecules to ecosystems, and to inform the development of integrated approaches for the identification and management of this and other invasive species.

Supplementary Materials: The following are available online at http://www.mdpi.com/2071-1050/12/11/4508/s1, Table S1. List of the available genomes for the European Xylella fastidiosa strains and associated features (data from NCBI). Strains without genomic resources are not included. Table S2. List of Xylella fastidiosa insect vector species (order Hemiptera) included in the BRIGIT project for which genomic resources will be available soon (details in the main text). Table S3. Spectral bands for the SENTINEL-2 sensors (S2A and S2B).

Author Contributions: Conceptualization, F.R. and L.B.; data curation, F.R. and L.B.; investigation, F.R. and L.B.; methodology, F.R., R.B., G.D. and L.B.; writing一original draft, F.R., G.B., R.B., G.D., D.R. and L.B.; writing一review \& editing, F.R., G.B., R.B., G.D., D.R. and L.B. All authors have read and agreed to the published version of the manuscript.

Funding: This research received no external funding.

Acknowledgments: We are grateful to Saskia Hogenhout and four anonymous reviewers for their valuable comments. RB is funded by the UK Research and Innovation through the Strategic Priorities Fund, by a grant from the Biotechnology and Biological Sciences Research Council with support from the Department for Environment, Food and Rural Affairs and the Scottish Government.

Conflicts of Interest: The authors declare no conflict of interests.

\section{References}

1. Williamson, M.; Griffiths, B. Biological Invasions; Springer Science \& Business Media: London, UK, 1996; ISBN 0-412-59190-1.

2. Levine, J.M. Biological invasions. Curr. Biol. 2008, 18, R57-R60. [CrossRef] [PubMed]

3. Hoffmann, B.D.; Broadhurst, L.M. The economic cost of managing invasive species in Australia. NeoBiota 2016, 31, 1. [CrossRef]

4. Hulme, P.E.; Pyšek, P.; Nentwig, W.; Vilà, M. Will threat of biological invasions unite the European Union? Science 2009, 324, 40-41. [CrossRef] [PubMed]

5. Charles, H.; Dukes, J.S. Impacts of Invasive Species on Ecosystem Services. In Biological Invasions; Nentwig, W., Ed.; Ecological Studies; Springer: Berlin/Heidelberg, Germany, 2008; pp. 217-237, ISBN 978-3-540-36920-2.

6. Bertolino, S.; Sciandra, C.; Bosso, L.; Russo, D.; Lurz, P.W.; Di Febbraro, M. Spatially explicit models as tools for implementing effective management strategies for invasive alien mammals. Mammal Rev. 2020. [CrossRef]

7. Thakur, M.P.; van der Putten, W.H.; Cobben, M.M.; van Kleunen, M.; Geisen, S. Microbial invasions in terrestrial ecosystems. Nat. Rev. Microbiol. 2019, 17, 621-631. [CrossRef]

8. Van der Putten, W.H.; Klironomos, J.N.; Wardle, D.A. Microbial ecology of biological invasions. ISME J. 2007, 1, 28-37. [CrossRef]

9. Litchman, E. Invisible invaders: Non-pathogenic invasive microbes in aquatic and terrestrial ecosystems. Ecol. Lett. 2010, 13, 1560-1572. [CrossRef]

10. Peeri, N.C.; Shrestha, N.; Rahman, M.S.; Zaki, R.; Tan, Z.; Bibi, S.; Baghbanzadeh, M.; Aghamohammadi, N.; Zhang, W.; Haque, U. The SARS, MERS and novel coronavirus (COVID-19) epidemics, the newest and biggest global health threats: What lessons have we learned? Int. J. Epidemiol. 2020. [CrossRef]

11. Ghelardini, L.; Luchi, N.; Pecori, F.; Pepori, A.L.; Danti, R.; Della Rocca, G.; Capretti, P.; Tsopelas, P.; Santini, A. Ecology of invasive forest pathogens. Biol. Invasions 2017, 19, 3183-3200. [CrossRef]

12. Wells, J.M.; Raju, B.C.; Hung, H.-Y.; Weisburg, W.G.; Mandelco-Paul, L.; Brenner, D.J. Xylella fastidiosa gen. nov., sp. nov: Gram-Negative, Xylem-Limited, Fastidious Plant Bacteria Related to Xanthomonas spp. Int. J. Syst. Evol. Microbiol. 1987, 37, 136-143. [CrossRef]

13. Bragard, C.; Dehnen-Schmutz, K.; Di Serio, F.; Gonthier, P.; Jacques, M.; Miret, J.A.J.; Justesen, A.F.; MacLeod, A.; Magnusson, C.S.; Milonas, P. Update of the Scientific Opinion on the risks to plant health posed by Xylella fastidiosa in the EU territory. EFSA J. 2019, 17. [CrossRef] 
14. Schneider, K.; van der Werf, W.; Cendoya, M.; Mourits, M.; Navas-Cortés, J.A.; Vicent, A.; Oude Lansink, A. Impact of Xylella fastidiosa subspecies pauca in European olives. Proc. Natl. Acad. Sci. USA 2020, 201912206. [CrossRef] [PubMed]

15. European and Mediterranean Plant Protection Organization. EPPO PM 7/24 (4) Xylella fastidiosa. EPPO Bull. 2019, 49, 175-227. [CrossRef]

16. Janse, J.; Obradovic, A. Xylella fastidiosa: Its biology, diagnosis, control and risks. J. Plant Pathol. 2010, S35-S48. [CrossRef]

17. Chatterjee, S.; Almeida, R.P.P.; Lindow, S. Living in two worlds: The plant and insect lifestyles of Xylella fastidiosa. Annu. Rev. Phytopathol. 2008, 46, 243-271. [CrossRef]

18. Sabella, E.; Aprile, A.; Genga, A.; Siciliano, T.; Nutricati, E.; Nicolì, F.; Vergine, M.; Negro, C.; De Bellis, L.; Luvisi, A. Xylem cavitation susceptibility and refilling mechanisms in olive trees infected by Xylella fastidiosa. Sci. Rep. 2019, 9, 1-11. [CrossRef]

19. Saponari, M.; Boscia, D.; Nigro, F.; Martelli, G. Identification of DNA sequences related to Xylella fastidiosa in oleander, almond and olive trees exhibiting leaf scorch symptoms in Apulia (Southern Italy). J. Plant Pathol. 2013, 95. [CrossRef]

20. European and Mediterranean Plant Protection Organization. EPPO Annual report and Council recommendations 2017. EPPO Bull. 2018, 48, 609-619. [CrossRef]

21. Landa, B.B.; Castillo, A.I.; Giampetruzzi, A.; Kahn, A.; Román-Écija, M.; Velasco-Amo, M.P.; Navas-Cortés, J.A.; Marco-Noales, E.; Barbé, S.; Moralejo, E. Emergence of a plant pathogen in Europe associated with multiple intercontinental introductions. Appl. Environ. Microbiol. 2020, 86. [CrossRef]

22. Frazier, N.W. Xylem viruses and their insect vectors. In Proceedings of the Proceedings International Conference on Virus and Vectors on Perennial Hosts, with Special Reference to Vitis, Davis, CA, USA, 6-10 September 1965.

23. Almeida, R.P.P.; Blua, M.J.; Lopes, J.R.S.; Purcell, A.H. Vector Transmission of Xylella fastidiosa: Applying Fundamental Knowledge to Generate Disease Management Strategies. Ann. Entomol. Soc. Am. 2005, 98, 775-786. [CrossRef]

24. Redak, R.A.; Purcell, A.H.; Lopes, J.R.S.; Blua, M.J.; Mizell, R.F., III; Andersen, P.C. The Biology of Xylem Fluid-Feeding Insect Vectors of Xylella fastidiosa and Their Relation to Disease Epidemiology. Annu. Rev. Entomol. 2004, 49, 243-270. [CrossRef] [PubMed]

25. Cornara, D.; Marra, M.; Tedone, B.; Cavalieri, V.; Porcelli, F.; Fereres, A.; Purcell, A.; Saponari, M. No evidence for cicadas' implication in Xylella fastidiosa epidemiology. Entomol. Gen. 2020, 125-132. [CrossRef]

26. European Food Safety Authority Panel on Plant Health (PLH). EFSA Scientific Opinion on the risks to plant health posed by Xylella fastidiosa in the EU territory, with the identification and evaluation of risk reduction options. EFSA J. 2015, 13, 3989. [CrossRef]

27. Severin, H. Spittle-insect vectors of Pierce's disease virus: II. Life history and virus transmission. Hilgardia 1950, 19, 357-382. [CrossRef]

28. Purcell, A.H. Almond Leaf Scorch: Leafhopper and Spittlebug Vectors. J. Econ. Entomol. 1980, 73, 834-838. [CrossRef]

29. Sanderlin, R.S.; Melanson, R.A. Insect Transmission of Xylella fastidiosa to Pecan. Plant Dis. 2010, 94, 465-470. [CrossRef]

30. Cornara, D.; Saponari, M.; Zeilinger, A.R.; de Stradis, A.; Boscia, D.; Loconsole, G.; Bosco, D.; Martelli, G.P.; Almeida, R.P.P.; Porcelli, F. Spittlebugs as vectors of Xylella fastidiosa in olive orchards in Italy. J. Pest Sci. 2017, 90, 521-530. [CrossRef]

31. Jeger, M.; Caffier, D.; Candresse, T.; Chatzivassiliou, E.; Dehnen-Schmutz, K.; Gilioli, G.; Grégoire, J.-C.; Miret, J.A.J.; MacLeod, A.; Navarro, M.N.; et al. Updated pest categorisation of Xylella fastidiosa. EFSA J. 2018, 16, e05357. [CrossRef]

32. Yurtsever, S. On the Polymorphic Meadow Spittlebug, Philaenus spumarius (L.) (Homoptera: Cercopidae). Turk. J. Zool. 2000, 24, 447-460.

33. Cavalieri, V.; Altamura, G.; Fumarola, G.; di Carolo, M.; Saponari, M.; Cornara, D.; Bosco, D.; Dongiovanni, C. Transmission of Xylella fastidiosa Subspecies Pauca Sequence Type 53 by Different Insect Species. Insects 2019, 10, 324. [CrossRef] 
34. Cornara, D.; Morente, M.; Markheiser, A.; Bodino, N.; Tsai, C.-T.; Fereres, A.; Redak, R.A.; Perring, T.M.; Spotti Lopes, J.R. An overview on the worldwide vectors of Xylella fastidiosa. Entomol. Gen. 2019, 39, 157-181. [CrossRef]

35. European and Mediterranean Plant Protection Organization. EPPO PM 7/141 (1) Philaenus spumarius, Philaenus italosignus and Neophilaenus campestris. EPPO Bull. 2020, epp.12610. [CrossRef]

36. Elbeaino, T.; Yaseen, T.; Valentini, F.; Ben Moussa, I.E.; Mazzoni, V.; D’onghia, A.M. Identification of three potential insect vectors of Xylella fastidiosa in southern Italy. Phytopathol. Mediterr. 2014, 53, 328-332. [CrossRef]

37. EFSA Panel on Plant Health (EFSA PLH Panel); Bragard, C.; Dehnen-Schmutz, K.; Di Serio, F.; Gonthier, P.; Jacques, M.-A.; Jaques Miret, J.A.; Justesen, A.F.; MacLeod, A.; Magnusson, C.S.; et al. Effectiveness of in planta control measures for Xylella fastidiosa. EFSA J. 2019, 17, e05666. [CrossRef]

38. Liccardo, A.; Fierro, A.; Garganese, F.; Picciotti, U.; Porcelli, F. A biological control model to manage the vector and the infection of Xylella fastidiosa on olive trees. PLOS ONE 2020, 15, e0232363. [CrossRef]

39. Catalano, L.; Shoki, A.-D.; Boscia, D.; Martelli, G.P. Guidelines for the Prevention, Eradication and Containment of Xylella Fastidiosa in Olive-Growing Areas; Food and Agriculture Organization of the United Nations: Cairo, Egypt, 2019; p. 64.

40. Lawson Handley, L.-J.; Estoup, A.; Evans, D.M.; Thomas, C.E.; Lombaert, E.; Facon, B.; Aebi, A.; Roy, H.E. Ecological genetics of invasive alien species. BioControl 2011, 56, 409-428. [CrossRef]

41. Bouyer, J.; Lancelot, R. Using genetic data to improve species distribution models. Infect. Genet. Evol. 2018, 63, 292-294. [CrossRef]

42. Yamasaki, E.; Altermatt, F.; Cavender-Bares, J.; Schuman, M.C.; Zuppinger-Dingley, D.; Garonna, I.; Schneider, F.D.; Guillén-Escribà, C.; van Moorsel, S.J.; Hahl, T.; et al. Genomics meets remote sensing in global change studies: Monitoring and predicting phenology, evolution and biodiversity. Curr. Opin. Environ. Sustain. 2017, 29, 177-186. [CrossRef]

43. Burger, M. Applying GIS and Remote Sensing to Landscape Genetics and Genome Size Research. Available online: https://pdfs.semanticscholar.org/3054/4c8c85b5bfc7e3f07725329376120473178a.pdf (accessed on 28 May 2020).

44. Waldvogel, A.-M.; Feldmeyer, B.; Rolshausen, G.; Exposito-Alonso, M.; Rellstab, C.; Kofler, R.; Mock, T.; Schmid, K.; Schmitt, I.; Bataillon, T.; et al. Evolutionary genomics can improve prediction of species' responses to climate change. Evol. Lett. 2020, 4, 4-18. [CrossRef]

45. Searle, J.B. The genetics of mammalian invasions: A review. Wildl. Res. 2008, 35, 185-192. [CrossRef]

46. Barrett, S.C.H. Foundations of invasion genetics: The Baker and Stebbins legacy. Mol. Ecol. 2015, 24, 1927-1941. [CrossRef]

47. Welles, S.R.; Dlugosch, K.M. Population Genomics of Colonization and Invasion. In Population Genomics: Concepts, Approaches and Applications; Rajora, O.P., Ed.; Population Genomics; Springer International Publishing: Cham, Switzerland, 2019; pp. 655-683, ISBN 978-3-030-04589-0.

48. Reznick, D.N.; Losos, J.; Travis, J. From low to high gear: There has been a paradigm shift in our understanding of evolution. Ecol. Lett. 2019, 22, 233-244. [CrossRef]

49. Dupuis, J.R.; Ruiz-Arce, R.; Barr, N.B.; Thomas, D.B.; Geib, S.M. Range-wide population genomics of the Mexican fruit fly: Toward development of pathway analysis tools. Evol. Appl. 2019,12,1641-1660. [CrossRef]

50. Makino, T.; Kawata, M. Invasive invertebrates associated with highly duplicated gene content. Mol. Ecol. 2019, 28, 1652-1663. [CrossRef]

51. Hamelin, R.C.; Roe, A.D. Genomic biosurveillance of forest invasive alien enemies: A story written in code. Evol. Appl. 2020, 13, 95-115. [CrossRef]

52. Hammond, A.; Galizi, R.; Kyrou, K.; Simoni, A.; Siniscalchi, C.; Katsanos, D.; Gribble, M.; Baker, D.; Marois, E.; Russell, S.; et al. A CRISPR-Cas9 gene drive system targeting female reproduction in the malaria mosquito vector Anopheles gambiae. Nat. Biotechnol. 2016, 34, 78-83. [CrossRef]

53. Kyrkou, I.; Pusa, T.; Ellegaard-Jensen, L.; Sagot, M.-F.; Hansen, L.H. Pierce's Disease of Grapevines: A Review of Control Strategies and an Outline of an Epidemiological Model. Front. Microbiol. 2018, 9. [CrossRef]

54. Huang, Y.; Chen, Y.; Zeng, B.; Wang, Y.; James, A.A.; Gurr, G.M.; Yang, G.; Lin, X.; Huang, Y.; You, M. CRISPR/Cas9 mediated knockout of the abdominal-A homeotic gene in the global pest, diamondback moth (Plutella xylostella). Insect Biochem. Mol. Biol. 2016, 75, 98-106. [CrossRef] 
55. Wu, N.; Zhang, S.; Li, X.; Cao, Y.; Liu, X.; Wang, Q.; Liu, Q.; Liu, H.; Hu, X.; Zhou, X.J.; et al. Fall webworm genomes yield insights into rapid adaptation of invasive species. Nat. Ecol. Evol. 2019, 3, 105-115. [CrossRef]

56. Simpson, A.J.G.; Reinach, F.C.; Arruda, P.; Abreu, F.A.; Acencio, M.; Alvarenga, R.; Alves, L.M.C.; Araya, J.E.; Baia, G.S.; Baptista, C.S.; et al. The genome sequence of the plant pathogen Xylella fastidiosa. Nature 2000, 406, 151-157. [CrossRef]

57. Retchless, A.C.; Labroussaa, F.; Shapiro, L.; Stenger, D.C.; Lindow, S.E.; Almeida, R.P.P. Genomic insights into Xylella fastidiosa interactions with plant and insect hosts. In Genomics of Plant-Associated Bacteria; Springer: Berlin/Heidelberg, Germany, 2014; pp. 177-202, ISBN 978-3-642-55378-3.

58. Vanhove, M.; Retchless, A.C.; Sicard, A.; Rieux, A.; Coletta-Filho, H.D.; Fuente, L.D.L.; Stenger, D.C.; Almeida, R.P.P. Genomic Diversity and Recombination among Xylella fastidiosa Subspecies. Appl. Environ. Microbiol. 2019, 85. [CrossRef]

59. Potnis, N.; Kandel, P.P.; Merfa, M.V.; Retchless, A.C.; Parker, J.K.; Stenger, D.C.; Almeida, R.P.P.; Bergsma-Vlami, M.; Westenberg, M.; Cobine, P.A.; et al. Patterns of inter- and intrasubspecific homologous recombination inform eco-evolutionary dynamics of Xylella fastidiosa. ISME J. 2019, 13, 2319-2333. [CrossRef]

60. Bhattacharyya, A.; Stilwagen, S.; Reznik, G.; Feil, H.; Feil, W.S.; Anderson, I.; Bernal, A.; D'Souza, M.; Ivanova, N.; Kapatral, V.; et al. Draft Sequencing and Comparative Genomics of Xylella fastidiosa Strains Reveal Novel Biological Insights. Genome Res. 2002, 12, 1556-1563. [CrossRef]

61. Chen, J.; Xie, G.; Han, S.; Chertkov, O.; Sims, D.; Civerolo, E.L. Whole Genome Sequences of Two Xylella fastidiosa Strains (M12 and M23) Causing Almond Leaf Scorch Disease in California. J. Bacteriol. 2010, 192, 4534. [CrossRef]

62. Giampetruzzi, A.; Chiumenti, M.; Saponari, M.; Donvito, G.; Italiano, A.; Loconsole, G.; Boscia, D.; Cariddi, C.; Martelli, G.P.; Saldarelli, P. Draft genome sequence of the Xylella fastidiosa CoDiRO strain. Genome Announc. 2015, 3, e01538-14. [CrossRef]

63. Giampetruzzi, A.; D’Attoma, G.; Zicca, S.; Abou Kubaa, R.; Rizzo, D.; Boscia, D.; Saldarelli, P.; Saponari, M. Draft Genome Sequence Resources of Three Strains (TOS4, TOS5, and TOS14) of Xylella fastidiosa Infecting Different Host Plants in the Newly Discovered Outbreak in Tuscany, Italy. Phytopathology 2019, 109, 1516-1518. [CrossRef]

64. Giampetruzzi, A.; Saponari, M.; Almeida, R.P.; Essakhi, S.; Boscia, D.; Loconsole, G.; Saldarelli, P. Complete genome sequence of the olive-infecting strain Xylella fastidiosa subsp. pauca De Donno. Genome Announc. 2017, 5, e00569-17. [CrossRef]

65. Guan, W.; Shao, J.; Zhao, T.; Huang, Q. Genome sequence of a Xylella fastidiosa strain causing mulberry leaf scorch disease in Maryland. Genome Announc. 2014, 2, e00916-13. [CrossRef]

66. Ramazzotti, M.; Cimaglia, F.; Gallo, A.; Ranaldi, F.; Surico, G.; Mita, G.; Bleve, G.; Marchi, G. Insights on a founder effect: The case of Xylella fastidiosa in the Salento area of Apulia, Italy. Phytopathol. Mediterr. 2018, 57, 8-25. [CrossRef]

67. Schreiber, H.L.; Koirala, M.; Lara, A.; Ojeda, M.; Dowd, S.E.; Bextine, B.; Morano, L. Unraveling the first Xylella fastidiosa subsp. fastidiosa genome from Texas. Southwest. Entomol. 2010, 35, 479-484. [CrossRef]

68. Besser, J.; Carleton, H.A.; Gerner-Smidt, P.; Lindsey, R.L.; Trees, E. Next-generation sequencing technologies and their application to the study and control of bacterial infections. Clin. Microbiol. Infect. Off. Publ. Eur. Soc. Clin. Microbiol. Infect. Dis. 2018, 24, 335-341. [CrossRef]

69. De Maio, N.; Shaw, L.P.; Hubbard, A.; George, S.; Sanderson, N.D.; Swann, J.; Wick, R.; AbuOun, M.; Stubberfield, E.; Hoosdally, S.J.; et al. Comparison of long-read sequencing technologies in the hybrid assembly of complex bacterial genomes. Microb. Genom. 2019, 5. [CrossRef]

70. Richardson, E.J.; Watson, M. The automatic annotation of bacterial genomes. Brief. Bioinform. 2013, 14, 1-12. [CrossRef]

71. Lemos de Macedo, E.G.; Alves, L.M.C.; Campanharo, J.C. Genomics-based design of defined growth media for the plant pathogen Xylella fastidiosa. FEMS Microbiol. Lett. 2003, 219, 39-45. [CrossRef]

72. Biello, R.; Mathers, T.C.; Mugford, S.T.; Liu, Q.; Rodrigues, A.S.B.; Neto, A.C.; Rebelo, M.T.; Paulo, O.S.; Seabra, S.G.; Hogenhout, S.A. Draft Genome Assembly Version 1 of the Meadow Spittlebug Philaenus spumarius (Linnaeus, 1758) (Hemiptera, Aphrophoridae). Available online: https://zenodo.org/record/3368385\# .Xs9ejMARXIU (accessed on 31 January 2020).

73. Almeida, R.P.P.; Nunney, L. How Do Plant Diseases Caused by Xylella fastidiosa Emerge? Plant Dis. 2015, 99, 1457-1467. [CrossRef] 
74. Denancé, N.; Briand, M.; Gaborieau, R.; Gaillard, S.; Jacques, M.-A. Identification of genetic relationships and subspecies signatures in Xylella fastidiosa. BMC Genom. 2019, 20, 239. [CrossRef]

75. Mang, S.M.; Frisullo, S.; Elshafie, H.S.; Camele, I. Diversity Evaluation of Xylella fastidiosa from Infected Olive Trees in Apulia (Southern Italy). Plant Pathol. J. 2016, 32, 102-111. [CrossRef]

76. Marcelletti, S.; Scortichini, M. Genome-wide comparison and taxonomic relatedness of multiple Xylella fastidiosa strains reveal the occurrence of three subspecies and a new Xylella species. Arch. Microbiol. 2016, 198, 803-812. [CrossRef]

77. Baldi, P.; La Porta, N. Xylella fastidiosa: Host Range and Advance in Molecular Identification Techniques. Front. Plant Sci. 2017, 8, 944. [CrossRef]

78. Bergsma-Vlami, M.; van de Bilt, J.L.J.; Tjou-Tam-Sin, N.N.A.; Helderman, C.M.; Gorkink-Smits, P.; Landman, N.M.; van Nieuwburg, J.G.W.; van Veen, E.J.; Westenberg, M. Assessment of the genetic diversity of Xylella fastidiosa in imported ornamental Coffea arabica plants. Plant Pathol. 2017, 66, 1065-1074. [CrossRef]

79. Bull, C.T.; Boer, S.H.D.; Denny, T.P.; Firrao, G.; Saux, M.F.-L.; Saddler, G.S.; Scortichini, M.; Stead, D.E.; Takikawa, Y. List of New Names of Plant Pathogenic Bacteria (2008-2010). J. Plant Pathol. 2012, 94, 21-27. [CrossRef]

80. Denancé, N.; Legendre, B.; Briand, M.; Olivier, V.; de Boisseson, C.; Poliakoff, F.; Jacques, M.-A. Several subspecies and sequence types are associated with the emergence of Xylella fastidiosa in natural settings in France. Plant Pathol. 2017, 66, 1054-1064. [CrossRef]

81. Nunney, L.; Azad, H.; Stouthamer, R. An Experimental Test of the Host-Plant Range of Nonrecombinant Strains of North American Xylella fastidiosa subsp. multiplex. Phytopathology 2019, 109, 294-300. [CrossRef]

82. Nunney, L.; Ortiz, B.; Russell, S.A.; Sánchez, R.R.; Stouthamer, R. The complex biogeography of the plant pathogen Xylella fastidiosa: Genetic evidence of introductions and subspecific introgression in Central America. PLoS ONE 2014, 9, e112463. [CrossRef] [PubMed]

83. Nunney, L.; Schuenzel, E.L.; Scally, M.; Bromley, R.E.; Stouthamer, R. Large-scale intersubspecific recombination in the plant-pathogenic bacterium Xylella fastidiosa is associated with the host shift to mulberry. Appl. Environ. Microbiol. 2014, 80, 3025-3033. [CrossRef]

84. Randall, J.J.; Goldberg, N.P.; Kemp, J.D.; Radionenko, M.; French, J.M.; Olsen, M.W.; Hanson, S.F. Genetic Analysis of a Novel Xylella fastidiosa Subspecies Found in the Southwestern United States. Appl. Environ. Microbiol. 2009, 75, 5631-5638. [CrossRef]

85. Schuenzel, E.L.; Scally, M.; Stouthamer, R.; Nunney, L. A Multigene Phylogenetic Study of Clonal Diversity and Divergence in North American Strains of the Plant Pathogen Xylella fastidiosa. Appl. Environ. Microbiol. 2005, 71, 3832-3839. [CrossRef]

86. Cruaud, A.; Gonzalez, A.-A.; Godefroid, M.; Nidelet, S.; Streito, J.-C.; Thuillier, J.-M.; Rossi, J.-P.; Santoni, S.; Rasplus, J.-Y. Using insects to detect, monitor and predict the distribution of Xylella fastidiosa: A case study in Corsica. Sci. Rep. 2018, 8, 1-13. [CrossRef]

87. Elbaino, T.; Valentini, F.; Abou Kubaa, R.; Moubarak, P.; Yaseen, T.; Digiaro, M. Multilocus sequence typing of Xylella fastidiosa isolated from olive affected by "olive quick decline syndrome" in Italy. Phytopathol. Mediterr. 2014, 53, 533-542.

88. Jacques, M.-A.; Denancé, N.; Legendre, B.; Morel, E.; Briand, M.; Mississipi, S.; Durand, K.; Olivier, V.; Portier, P.; Poliakoff, F.; et al. New Coffee Plant-Infecting Xylella fastidiosa Variants Derived via Homologous Recombination. Appl. Environ. Microbiol. 2016, 82, 1556. [CrossRef]

89. Doddapaneni, H.; Francis, M.; Yao, J.; Lin, H.; Civerolo, E.L. Genome-wide analysis of Xylella fastidiosa: Implications for detection and strain relationships. Afr. J. Biotechnol. 2007, 6, 055-066.

90. Yuan, X.; Morano, L.; Bromley, R.; Spring-Pearson, S.; Stouthamer, R.; Nunney, L. Multilocus Sequence Typing of Xylella fastidiosa Causing Pierce's Disease and Oleander Leaf Scorch in the United States. Phytopathology 2010, 100, 601-611. [CrossRef]

91. Burbank, L.P.; Ortega, B.C. Novel amplification targets for rapid detection and differentiation of Xylella fastidiosa subspecies fastidiosa and multiplex in plant and insect tissues. J. Microbiol. Methods 2018, 155, 8-18. [CrossRef] [PubMed]

92. European and Mediterranean Plant Protection Organization. EPPO PM 7/24 (3) Xylella fastidiosa. EPPO Bull. 2018, 48, 175-218. [CrossRef] 
93. Loconsole, G.; Potere, O.; Boscia, D.; Altamura, G.; Djelouah, K.; Elbeaino, T.; Frasheri, D.; Lorusso, D.; Palmisano, F.; Pollastro, P. Detection of Xylella fastidiosa in olive trees by molecular and serological methods. J. Plant Pathol. 2014, 96,7-14. [CrossRef]

94. Loconsole, G.; Saponari, M.; Boscia, D.; D'Attoma, G.; Morelli, M.; Martelli, G.P.; Almeida, R.P.P. Intercepted isolates of Xylella fastidiosa in Europe reveal novel genetic diversity. Eur. J. Plant Pathol. 2016, 146, 85-94. [CrossRef]

95. Maiden, M.C. Multilocus sequence typing of bacteria. Annu. Rev. Microbiol. 2016, 60, 561-588. [CrossRef]

96. Horizon 2020. Pest Organisms Threatening Europe. In Proceedings of the XFactors European Conference on Xylella fastidiosa and Project Annual Meetings, Palma de Mallorca, Spain, 13-15 November 2017.

97. Barbosa, D.; Alencar, V.C.; Santos, D.S.; de Freitas Oliveira, A.C.; de Souza, A.A.; Coletta-Filho, H.D.; Costa de Oliveira, R.; Nunes, L.R. Comparative genomic analysis of coffee-infecting Xylella fastidiosa strains isolated from Brazil. Microbiology 2015, 161, 1018-1033. [CrossRef]

98. Bleve, G.; Marchi, G.; Rinaldi, F.; Gallo, A.; Cimaglia, F.; Logrieco, A.F.; Mita, G.; Ristori, J.; Surico, G. Molecular characteristics of a strain (Salento-1) of Xylella fastidiosa isolated in Apulia (Italy) from an olive plant with the quick decline syndrome. Phytopathol. Mediterr. 2016, 55, 139-146. [CrossRef]

99. Parker, J.K.; Havird, J.C.; De La Fuente, L. Differentiation of Xylella fastidiosa Strains via Multilocus Sequence Analysis of Environmentally Mediated Genes (MLSA-E). Appl. Environ. Microbiol. 2012, 78, 1385. [CrossRef]

100. Cella, E.; Angeletti, S.; Fogolari, M.; Bazzardi, R.; De Gara, L.; Ciccozzi, M. Two different Xylella fastidiosa strains circulating in Italy: Phylogenetic and evolutionary analyses. J. Plant Interact. 2018, 13, 428-432. [CrossRef]

101. Giampetruzzi, A.; Loconsole, G.; Boscia, D.; Calzolari, A.; Chiumenti, M.; Martelli, G.P.; Saldarelli, P.; Almeida, R.P.; Saponari, M. Draft genome sequence of CO33, a coffee-infecting isolate of Xylella fastidiosa. Genome Announc. 2015, 3, e01472-15. [CrossRef] [PubMed]

102. Giampetruzzi, A.; Saponari, M.; Loconsole, G.; Boscia, D.; Savino, V.N.; Almeida, R.P.; Zicca, S.; Landa, B.B.; Chacón-Diaz, C.; Saldarelli, P. Genome-wide analysis provides evidence on the genetic relatedness of the emergent Xylella fastidiosa genotype in Italy to isolates from Central America. Phytopathology 2017, 107, 816-827. [CrossRef] [PubMed]

103. Moralejo, E.; Borràs, D.; Gomila, M.; Montesinos, M.; Adrover, F.; Juan, A.; Nieto, A.; Olmo, D.; Seguí, G.; Landa, B.B. Insights into the epidemiology of Pierce's disease in vineyards of Mallorca, Spain. Plant Pathol. 2019, 68, 1458-1471. [CrossRef]

104. Nunney, L.; Yuan, X.; Bromley, R.E.; Stouthamer, R. Detecting Genetic Introgression: High Levels of Intersubspecific Recombination Found in Xylella fastidiosa in Brazil. Appl. Environ. Microbiol. 2012, 78, 4702-4714. [CrossRef] [PubMed]

105. Nunney, L.; Yuan, X.; Bromley, R.; Hartung, J.; Montero-Astúa, M.; Moreira, L.; Ortiz, B.; Stouthamer, R. Population Genomic Analysis of a Bacterial Plant Pathogen: Novel Insight into the Origin of Pierce's Disease of Grapevine in the U.S. PLoS ONE 2010, 5, e15488. [CrossRef]

106. Saponari, M.; Giampetruzzi, A.; Loconsole, G.; Boscia, D.; Saldarelli, P. Xylella fastidiosa in Olive in Apulia: Where We Stand. Phytopathology 2018, 109, 175-186. [CrossRef]

107. Coletta-Filho, H.D.; Francisco, C.S.; Lopes, J.R.S.; Muller, C.; Almeida, R.P.P. Homologous Recombination and Xylella fastidiosa Host-Pathogen Associations in South America. Phytopathology 2016, 107, 305-312. [CrossRef]

108. Kung, S.H.; Almeida, R.P.P. Natural Competence and Recombination in the Plant Pathogen Xylella fastidiosa. Appl. Environ. Microbiol. 2011, 77, 5278-5284. [CrossRef]

109. Scally, M.; Schuenzel, E.L.; Stouthamer, R.; Nunney, L. Multilocus sequence type system for the plant pathogen Xylella fastidiosa and relative contributions of recombination and point mutation to clonal diversity. Appl. Environ. Microbiol. 2005, 71, 8491-8499. [CrossRef]

110. Chen, H.; De La Fuente, L. Calcium transcriptionally regulates movement, recombination and other functions of Xylella fastidiosa under constant flow inside microfluidic chambers. Microb. Biotechnol. 2019. [CrossRef] [PubMed]

111. Nunes, L.R.; Rosato, Y.B.; Muto, N.H.; Yanai, G.M.; da Silva, V.S.; Leite, D.B.; Gonçalves, E.R.; de Souza, A.A.; Coletta-Filho, H.D.; Machado, M.A.; et al. Microarray Analyses of Xylella fastidiosa Provide Evidence of Coordinated Transcription Control of Laterally Transferred Elements. Genome Res. 2003, 13, 570-578. [CrossRef] [PubMed] 
112. De Mello Varani, A.; Souza, R.C.; Nakaya, H.I.; de Lima, W.C.; Paula de Almeida, L.G.; Kitajima, E.W.; Chen, J.; Civerolo, E.; Vasconcelos, A.T.R.; Van Sluys, M.-A. Origins of the Xylella fastidiosa Prophage-Like Regions and Their Impact in Genome Differentiation. PLoS ONE 2008, 3. [CrossRef] [PubMed]

113. Giampetruzzi, A.; Velasco-Amo, M.P.; Marco-Noales, E.; Montes-Borrego, M.; Román-Écija, M.; Navarro, I.; Monterde, A.; Barbé, S.; Almeida, R.P.P.; Saldarelli, P.; et al. Draft Genome Resources of Two Strains ("ESVL" and "IVIA5901") of Xylella fastidiosa Associated with Almond Leaf Scorch Disease in Alicante, Spain. Phytopathology 2018, 109, 219-221. [CrossRef] [PubMed]

114. Gomila, M.; Moralejo, E.; Busquets, A.; Segui, G.; Olmo, D.; Nieto, A.; Juan, A.; Lalucat, J. Draft Genome Resources of Two Strains of Xylella fastidiosa XYL1732/17 and XYL2055/17 Isolated from Mallorca Vineyards. Phytopathology 2019, 109, 222-224. [CrossRef]

115. Van Horn, C.; Wu, F.; Zheng, Z.; Dai, Z.; Chen, J. Detection of a Single-Copy Plasmid, pXFSL21, in Xylella fastidiosa Strain Stag's Leap with Two Toxin-Antitoxin Systems Using Next-Generation Sequencing. Phytopathology 2018, 109, 240-247. [CrossRef]

116. Schürch, A.C.; Arredondo-Alonso, S.; Willems, R.J.L.; Goering, R.V. Whole genome sequencing options for bacterial strain typing and epidemiologic analysis based on single nucleotide polymorphism versus gene-by-gene-based approaches. Clin. Microbiol. Infect. 2018, 24, 350-354. [CrossRef]

117. Yurtsever, S. Population genetics of Philaenus spumaris on the Istrianca mountanins: II. polymorphism and phenotype frequency. Acta Zool. Acad. Sci. Hung. 2004, 50, 25-34.

118. Rodrigues, A.S.B.; Silva, S.E.; Pina-Martins, F.; Loureiro, J.; Castro, M.; Gharbi, K.; Johnson, K.P.; Dietrich, C.H.; Borges, P.A.V.; Quartau, J.A.; et al. Assessing genotype-phenotype associations in three dorsal colour morphs in the meadow spittlebug Philaenus spumarius (L.) (Hemiptera: Aphrophoridae) using genomic and transcriptomic resources. BMC Genet. 2016, 17, 144. [CrossRef]

119. Rodrigues, A.S.B.; Silva, S.E.; Marabuto, E.; Silva, D.N.; Wilson, M.R.; Thompson, V.; Yurtsever, S.; Halkka, A.; Borges, P.A.V.; Quartau, J.A.; et al. New Mitochondrial and Nuclear Evidences Support Recent Demographic Expansion and an Atypical Phylogeographic Pattern in the Spittlebug Philaenus spumarius (Hemiptera, Aphrophoridae). PLoS ONE 2014, 9. [CrossRef]

120. Campanharo, J.C.; Lemos, M.V.F.; de Lemos, E.G.M. Growth optimization procedures for the phytopathogen Xylella fastidiosa. Curr. Microbiol. 2003, 46, 99-102. [CrossRef] [PubMed]

121. Cardinale, M.; Luvisi, A.; Meyer, J.B.; Sabella, E.; De Bellis, L.; Cruz, A.C.; Ampatzidis, Y.; Cherubini, P. Specific Fluorescence in Situ Hybridization (FISH) Test to Highlight Colonization of Xylem Vessels by Xylella fastidiosa in Naturally Infected Olive Trees (Olea europaea L.). Front. Plant Sci. 2018, 9. [CrossRef] [PubMed]

122. Djelouah, K.; Frasheri, D.; Valentini, F.; D'Onghia, A.M.; Digiaro, M. Direct tissue blot immunoassay for detection of Xylella fastidiosa in olive trees. Phytopathol. Mediterr. 2014, 53, 559-564.

123. Potere, O.; Susca, L.; Loconsole, G.; Saponari, M.; Boscia, D.; Savino, V.N.; Martelli, G.P. Survey for the presence of Xylella fastidiosa subsp. pauca strain CoDiRO in some forestry and ornamental species in the Salento peninsula. J. Plant Pathol. 2015, 97,373-376.

124. Saponari, M.; Boscia, D.; Altamura, G.; D’Attoma, G.; Cavalieri, V.; Zicca, S.; Morelli, M.; Tavano, D.; Loconsole, G.; Susca, L. Pilot project on Xylella fastidiosa to reduce risk assessment uncertainties. EFSA Support. Publ. 2016, 13, EN-1013. [CrossRef]

125. Novelli, S.; Gismondi, A.; Di Marco, G.; Canuti, L.; Nanni, V.; Canini, A. Plant defense factors involved in Olea europaea resistance against Xylella fastidiosa infection. J. Plant Res. 2019, 132, 439-455. [CrossRef] [PubMed]

126. Reisenzein, H. PCR assays for the detection of Xylella fastidiosa: Review and comparison of published protocols. In Xylella Fastidiosa \& the Olive Quick Decline Syndrome (OQDS): A Serious Worldwide Challenge for the Safeguard of Olive Trees; CIHEAM: Bari, Italy, 2017; pp. 57-60.

127. Martinelli, F.; Scalenghe, R.; Davino, S.; Panno, S.; Scuderi, G.; Ruisi, P.; Villa, P.; Stroppiana, D.; Boschetti, M.; Goulart, L.R.; et al. Advanced methods of plant disease detection. A review. Agron. Sustain. Dev. 2015, 35, 1-25. [CrossRef]

128. Modesti, V.; Pucci, N.; Lucchesi, S.; Campus, L.; Loreti, S. Experience of the Latium region (Central Italy) as a pest-free area for monitoring of Xylella fastidiosa: Distinctive features of molecular diagnostic methods. Eur. J. Plant Pathol. 2017, 148, 557-566. [CrossRef] 
129. Bonants, P.; Griekspoor, Y.; Houwers, I.; Krijger, M.; van der Zouwen, P.; van der Lee, T.A.; van der Wolf, J. Development and Evaluation of a Triplex TaqMan Assay and Next-Generation Sequence Analysis for Improved Detection of Xylella in Plant Material. Plant Dis. 2019, 103, 645-655. [CrossRef]

130. Dupas, E.; Briand, M.; Jacques, M.-A.; Cesbron, S. Novel tetraplex qPCR assays for simultaneous detection and identification of Xylella fastidiosa subspecies in plant tissues. Front. Plant Sci. 2019, 10, 1732. [CrossRef]

131. Faino, L.; Scala, V.; Albanese, A.; Modesti, V.; Grottoli, A.; Pucci, N.; L'Aurora, A.; Reverberi, M.; Loreti, S. Nanopore sequencing for the detection and the identification of Xylella fastidiosa subspecies and sequence types from naturally infected plant material. bioRxiv 2019, 810648. [CrossRef]

132. Chiriacò, M.S.; Luvisi, A.; Primiceri, E.; Sabella, E.; De Bellis, L.; Maruccio, G. Development of a lab-on-a-chip method for rapid assay of Xylella fastidiosa subsp. pauca strain CoDiRO. Sci. Rep. 2018, 8, 7376. [CrossRef] [PubMed]

133. Schrader, C.; Schielke, A.; Ellerbroek, L.; Johne, R. PCR inhibitors-occurrence, properties and removal. J. Appl. Microbiol. 2012, 113, 1014-1026. [CrossRef] [PubMed]

134. Harper, S.J.; Ward, L.I.; Clover, G.R.G. Development of LAMP and real-time PCR methods for the rapid detection of Xylella fastidiosa for quarantine and field applications. Phytopathology 2010, 100, 1282-1288. [CrossRef]

135. Sipahioglu, H.M.; Usta, M.; Ocak, M. Use of dried high-phenolic laden host leaves for virus and viroid preservation and detection by PCR methods. J. Virol. Methods 2006, 137, 120-124. [CrossRef]

136. Witte, A.K.; Sickha, R.; Mester, P.; Fister, S.; Schoder, D.; Rossmanith, P. Essential role of polymerases for assay performance-Impact of polymerase replacement in a well-established assay. Biomol. Detect. Quantif. 2018, 16, 12-20. [CrossRef]

137. Martinelli, F.; Marchese, A.; Giovino, A.; Marra, F.P.; Della Noce, I.; Caruso, T.; Dandekar, A.M. In-Field and Early Detection of Xylella fastidiosa Infections in Olive Using a Portable Instrument. Front. Plant Sci. 2019, 9. [CrossRef]

138. Nicolì, F.; Negro, C.; Nutricati, E.; Vergine, M.; Aprile, A.; Sabella, E.; Damiano, G.; De Bellis, L.; Luvisi, A. Accumulation of Azelaic Acid in Xylella fastidiosa-Infected Olive Trees: A Mobile Metabolite for Health Screening. Phytopathology 2018, 109, 318-325. [CrossRef]

139. Boncristiani, H.; Li, J.; Evans, J.D.; Pettis, J.; Chen, Y. Scientific note on PCR inhibitors in the compound eyes of honey bees, Apis mellifera. Apidologie 2011, 42, 457-460. [CrossRef]

140. Shamim, G.; Ranjan, S.K.; Pandey, D.M.; Ramani, R. Biochemistry and biosynthesis of insect pigments. EJE 2014, 111, 149-164. [CrossRef]

141. European and Mediterranean Plant Protection Organization. EPPO PM 7/129 (1) DNA barcoding as an identification tool for a number of regulated pests. EPPO Bull. 2016, 46, 501-537. [CrossRef]

142. Rach, J.; Bergmann, T.; Paknia, O.; DeSalle, R.; Schierwater, B.; Hadrys, H. The marker choice: Unexpected resolving power of an unexplored CO1 region for layered DNA barcoding approaches. PLoS ONE 2017, 12, e0174842. [CrossRef] [PubMed]

143. Marquina, D.; Andersson, A.F.; Ronquist, F. New mitochondrial primers for metabarcoding of insects, designed and evaluated using in silico methods. Mol. Ecol. Resour. 2019, 19, 90-104. [CrossRef] [PubMed]

144. Crampton-Platt, A.; Yu, D.W.; Zhou, X.; Vogler, A.P. Mitochondrial metagenomics: Letting the genes out of the bottle. GigaScience 2016, 5, 15. [CrossRef] [PubMed]

145. Cicconardi, F.; Borges, P.A.V.; Strasberg, D.; Oromí, P.; López, H.; Pérez-Delgado, A.J.; Casquet, J.; Caujapé-Castells, J.; Fernández-Palacios, J.M.; Thébaud, C.; et al. MtDNA metagenomics reveals large-scale invasion of belowground arthropod communities by introduced species. Mol. Ecol. 2017, 26, 3104-3115. [CrossRef] [PubMed]

146. Zhou, X.; Li, Y.; Liu, S.; Yang, Q.; Su, X.; Zhou, L.; Tang, M.; Fu, R.; Li, J.; Huang, Q. Ultra-deep sequencing enables high-fidelity recovery of biodiversity for bulk arthropod samples without PCR amplification. GigaScience 2013, 2, 4. [CrossRef]

147. Deiner, K.; Bik, H.M.; Mächler, E.; Seymour, M.; Lacoursière-Roussel, A.; Altermatt, F.; Creer, S.; Bista, I.; Lodge, D.M.; de Vere, N.; et al. Environmental DNA metabarcoding: Transforming how we survey animal and plant communities. Mol. Ecol. 2017, 26, 5872-5895. [CrossRef]

148. Ciraulo, M.B.; Santos, D.S.; de Rodrigues, A.C.F.O.; de Oliveira, M.V.; Rodrigues, T.; de Oliveira, R.C.; Nunes, L.R. Transcriptome Analysis of the Phytobacterium Xylella fastidiosa Growing under Xylem-Based 
Chemical Conditions. Available online: https://www.hindawi.com/journals/bmri/2010/781365/ (accessed on 4 December 2019).

149. Federici, M.T.; Marcondes, J.A.; Picchi, S.C.; Stuchi, E.S.; Fadel, A.L.; Laia, M.L.; Lemos, M.V.F.; Lemos, E.G.M. Xylella fastidiosa: An in vivo system to study possible survival strategies within citrus xylem vessels based on global gene expression analysis. Electron. J. Biotechnol. 2012, 15, 4. [CrossRef]

150. De Travensolo, R.F.; Costa, M.V.C.G.; Carareto-Alves, L.M.; Carrilho, E.; de Lemos, E.G.M. Production of DNA microarray and expression analysis of genes from Xylella fastidiosa in different culture media. Braz. Arch. Biol. Technol. 2009, 52, 555-566. [CrossRef]

151. Travensolo, R.F.; Carareto-Alves, L.M.; Costa, M.V.C.G.; Lopes, T.J.S.; Carrilho, E.; Lemos, E.G.M. Xylella fastidiosa gene expression analysis by DNA microarrays. Genet. Mol. Biol. 2009, 32, 340-353. [CrossRef]

152. Gambetta, G.A.; Matthews, M.A.; Syvanen, M. The Xylella fastidosa RTX operons: Evidence for the evolution of protein mosaics through novel genetic exchanges. BMC Genom. 2018, 19, 329. [CrossRef]

153. Li, W.B.; Zhou, C.H.; Pria, W.D.; Teixeira, D.C.; Miranda, V.S.; Pereira, E.O.; Ayres, A.J.; He, C.-X.; Costa, P.I.; Hartung, J.S. Citrus and Coffee Strains of Xylella fastidiosa Induce Pierce's Disease in Grapevine. Plant Dis. 2002, 86, 1206-1210. [CrossRef]

154. Abou Kubaa, R.; Giampetruzzi, A.; Altamura, G.; Saponari, M.; Saldarelli, P. Infections of the Xylella fastidiosa subsp. pauca Strain "De Donno" in Alfalfa (Medicago sativa) Elicits an Overactive Immune Response. Plants 2019, 8, 335. [CrossRef]

155. Sabella, E.; Luvisi, A.; Aprile, A.; Negro, C.; Vergine, M.; Nicolì, F.; Miceli, A.; De Bellis, L. Xylella fastidiosa induces differential expression of lignification related-genes and lignin accumulation in tolerant olive trees cv. Leccino. J. Plant Physiol. 2018, 220, 60-68. [CrossRef] [PubMed]

156. Zaini, P.A.; Nascimento, R.; Gouran, H.; Cantu, D.; Chakraborty, S.; Phu, M.; Goulart, L.R.; Dandekar, A.M. Molecular Profiling of Pierce's Disease Outlines the Response Circuitry of Vitis vinifera to Xylella fastidiosa Infection. Front. Plant Sci. 2018, 9, 771. [CrossRef] [PubMed]

157. De Pascali, M.; Vergine, M.; Sabella, E.; Aprile, A.; Nutricati, E.; Nicolì, F.; Buja, I.; Negro, C.; Miceli, A.; Rampino, P.; et al. Molecular Effects of Xylella fastidiosa and Drought Combined Stress in Olive Trees. Plants 2019, 8, 437. [CrossRef] [PubMed]

158. Rapicavoli, J.; Ingel, B.; Blanco-Ulate, B.; Cantu, D.; Roper, C. Xylella fastidiosa: An examination of a re-emerging plant pathogen. Mol. Plant Pathol. 2018, 19, 786-800. [CrossRef]

159. Giampetruzzi, A.; Morelli, M.; Saponari, M.; Loconsole, G.; Chiumenti, M.; Boscia, D.; Savino, V.N.; Martelli, G.P.; Saldarelli, P. Transcriptome profiling of two olive cultivars in response to infection by the CoDiRO strain of Xylella fastidiosa subsp. pauca. BMC Genom. 2016, 17, 475. [CrossRef]

160. D'Attoma, G.; Morelli, M.; Saldarelli, P.; Saponari, M.; Giampetruzzi, A.; Boscia, D.; Savino, V.N.; De La Fuente, L.; Cobine, P.A. Ionomic Differences between Susceptible and Resistant Olive Cultivars Infected by Xylella fastidiosa in the Outbreak Area of Salento, Italy. Pathogens 2019, 8, 272. [CrossRef]

161. Parker, J.K.; Chen, H.; McCarty, S.E.; Liu, L.Y.; De La Fuente, L. Calcium transcriptionally regulates the biofilm machinery of Xylella fastidiosa to promote continued biofilm development in batch cultures. Environ. Microbiol. 2016, 18, 1620-1634. [CrossRef]

162. Rodrigues, C.M.; de Souza, A.A.; Takita, M.A.; Kishi, L.T.; Machado, M.A. RNA-Seq analysis of Citrus reticulata in the early stages of Xylella fastidiosa infection reveals auxin-related genes as a defense response. BMC Genom. 2013, 14, 676. [CrossRef] [PubMed]

163. Workman, R.E.; Tang, A.D.; Tang, P.S.; Jain, M.; Tyson, J.R.; Razaghi, R.; Zuzarte, P.C.; Gilpatrick, T.; Payne, A.; Quick, J.; et al. Nanopore native RNA sequencing of a human poly(A) transcriptome. Nat. Methods 2019, 16, 1297-1305. [CrossRef]

164. Kukurba, K.R.; Montgomery, S.B. RNA Sequencing and Analysis. Cold Spring Harb. Protoc. $2015,2015$. [CrossRef] [PubMed]

165. Mathers, T.C.; Chen, Y.; Kaithakottil, G.; Legeai, F.; Mugford, S.T.; Baa-Puyoulet, P.; Bretaudeau, A.; Clavijo, B.; Colella, S.; Collin, O.; et al. Rapid transcriptional plasticity of duplicated gene clusters enables a clonally reproducing aphid to colonise diverse plant species. Genome Biol. 2017, 18, 27. [CrossRef] [PubMed]

166. De la Celorio-Mancera, M.P.; Wheat, C.W.; Huss, M.; Vezzi, F.; Neethiraj, R.; Reimegård, J.; Nylin, S.; Janz, N. Evolutionary history of host use, rather than plant phylogeny, determines gene expression in a generalist butterfly. BMC Evol. Biol. 2016, 16, 59. [CrossRef] [PubMed] 
167. Pym, A.; Singh, K.S.; Nordgren, Å.; Davies, T.G.E.; Zimmer, C.T.; Elias, J.; Slater, R.; Bass, C. Host plant adaptation in the polyphagous whitefly, Trialeurodes vaporariorum, is associated with transcriptional plasticity and altered sensitivity to insecticides. BMC Genom. 2019, 20, 996. [CrossRef]

168. Chen, C.; Bock, C.H.; Brannen, P.M. Novel Primers and Sampling for PCR Detection of Xylella fastidiosa in Peach. Phytopathology 2019, 109, 307-317. [CrossRef]

169. Shelake, R.M.; Pramanik, D.; Kim, J.-Y. Exploration of Plant-Microbe Interactions for Sustainable Agriculture in CRISPR Era. Microorganisms 2019, 7, 269. [CrossRef]

170. Da Silva Neto, J.F.; Koide, T.; Gomes, S.L.; Marques, M.V. Site-directed gene disruption in Xylella fastidiosa. FEMS Microbiol. Lett. 2002, 210, 105-110. [CrossRef]

171. Kandel, P.P.; Chen, H.; De La Fuente, L. A Short Protocol for Gene Knockout and Complementation in Xylella fastidiosa Shows that One of the Type IV Pilin Paralogs (PD1926) Is Needed for Twitching while Another (PD1924) Affects Pilus Number and Location. Appl. Environ. Microbiol. 2018, 84. [CrossRef] [PubMed]

172. Monteiro, P.B.; Teixeira, D.C.; Palma, R.R.; Garnier, M.; Bové, J.-M.; Renaudin, J. Stable Transformation of the Xylella fastidiosa Citrus Variegated Chlorosis Strain withoriC Plasmids. Appl. Environ. Microbiol. 2001, 67, 2263-2269. [CrossRef] [PubMed]

173. Yan, Q.; Fong, S.S. Challenges and Advances for Genetic Engineering of Non-model Bacteria and Uses in Consolidated Bioprocessing. Front. Microbiol. 2017, 8. [CrossRef] [PubMed]

174. Cruz, L.F.; Parker, J.K.; Cobine, P.A.; Fuente, L.D.L. Calcium-Enhanced Twitching Motility in Xylella fastidiosa Is Linked to a Single PilY1 Homolog. Appl. Environ. Microbiol. 2014, 80, 7176-7185. [CrossRef] [PubMed]

175. Matsumoto, A.; Young, G.M.; Igo, M.M. Chromosome-Based Genetic Complementation System for Xylella fastidiosa. Appl. Environ. Microbiol. 2009, 75, 1679-1687. [CrossRef] [PubMed]

176. Meng, Y.; Li, Y.; Galvani, C.D.; Hao, G.; Turner, J.N.; Burr, T.J.; Hoch, H.C. Upstream Migration of Xylella fastidiosa via Pilus-Driven Twitching Motility. J. Bacteriol. 2005, 187, 5560-5567. [CrossRef] [PubMed]

177. Navarrete, F.; De La Fuente, L. Zinc Detoxification Is Required for Full Virulence and Modification of the Host Leaf Ionome by Xylella fastidiosa. Mol. Plant-Microbe Interact. 2015, 28, 497-507. [CrossRef] [PubMed]

178. Newman, K.L.; Almeida, R.P.P.; Purcell, A.H.; Lindow, S.E. Cell-cell signaling controls Xylella fastidiosa interactions with both insects and plants. Proc. Natl. Acad. Sci. USA 2004, 101, 1737-1742. [CrossRef]

179. Roper, M.C.; Greve, L.C.; Warren, J.G.; Labavitch, J.M.; Kirkpatrick, B.C. Xylella fastidiosa Requires Polygalacturonase for Colonization and Pathogenicity in Vitis vinifera Grapevines. Mol. Plant-Microbe Interact. 2007, 20, 411-419. [CrossRef]

180. Hao, L.; Johnson, K.; Cursino, L.; Mowery, P.; Burr, T.J. Characterization of the Xylella fastidiosa PD1311 gene mutant and its suppression of Pierce's disease on grapevines. Mol. Plant Pathol. 2017, 18, 684-694. [CrossRef]

181. Killiny, N.; Almeida, R.P.P. Gene regulation mediates host specificity of a bacterial pathogen. Environ. Microbiol. Rep. 2011, 3, 791-797. [CrossRef]

182. Lee, M.W.; Tan, C.C.; Rogers, E.E.; Stenger, D.C. Toxin-antitoxin systems mqsR/ygiT and dinJ/relE of Xylella fastidiosa. Physiol. Mol. Plant Pathol. 2014, 87, 59-68. [CrossRef]

183. Merfa, M.V.; Niza, B.; Takita, M.A.; De Souza, A.A. The MqsRA Toxin-Antitoxin System from Xylella fastidiosa Plays a Key Role in Bacterial Fitness, Pathogenicity, and Persister Cell Formation. Front. Microbiol. 2016, 7, 904. [CrossRef] [PubMed]

184. Reddy, J.D.; Reddy, S.L.; Hopkins, D.L.; Gabriel, D.W. TolC is Required for Pathogenicity of Xylella fastidiosa in Vitis vinifera Grapevines. Mol. Plant-Microbe Interact. 2007, 20, 403-410. [CrossRef] [PubMed]

185. Das, M.; Bhowmick, T.S.; Ahern, S.J.; Young, R.; Gonzalez, C.F. Control of Pierce's Disease by Phage. PLoS ONE 2015, 10, e0128902. [CrossRef] [PubMed]

186. Dandekar, A.M.; Gouran, H.; Ibáñez, A.M.; Uratsu, S.L.; Agüero, C.B.; McFarland, S.; Borhani, Y.; Feldstein, P.A.; Bruening, G.; Nascimento, R.; et al. An engineered innate immune defense protects grapevines from Pierce disease. Proc. Natl. Acad. Sci. USA 2012, 109, 3721. [CrossRef]

187. Li, Z.T.; Hopkins, D.L.; Gray, D.J. Overexpression of antimicrobial lytic peptides protects grapevine from Pierce's disease under greenhouse but not field conditions. Transgenic Res. 2015, 24, 821-836. [CrossRef]

188. Caserta, R.; Souza-Neto, R.R.; Takita, M.A.; Lindow, S.E.; De Souza, A.A. Ectopic Expression of Xylella fastidiosa rpfF Conferring Production of Diffusible Signal Factor in Transgenic Tobacco and Citrus Alters Pathogen Behavior and Reduces Disease Severity. Mol. Plant-Microbe Interact. 2017, 30, 866-875. [CrossRef] 
189. Gilchrist, D.; Lincoln, J.E.; Esser, T. Systemic control of Pierce's disease by altered expression of anti-apoptotic genes or their RNA-based regulatory elements. In Proceedings of the Pierce's Disease Research Symposium, San Diego, CA, USA, 15-17 December 2008; pp. 208-213.

190. Lindow, S.; Newman, K.; Chatterjee, S.; Baccari, C.; Iavarone, A.T.; Ionescu, M. Production of Xylella fastidiosa Diffusible Signal Factor in Transgenic Grape Causes Pathogen Confusion and Reduction in Severity of Pierce's Disease. Mol. Plant-Microbe Interact. 2014, 27, 244-254. [CrossRef]

191. Zaidi, S.S.-A.; Mukhtar, M.S.; Mansoor, S. Genome Editing: Targeting Susceptibility Genes for Plant Disease Resistance. Trends Biotechnol. 2018, 36, 898-906. [CrossRef]

192. Low, L.-Y.; Yang, S.-K.; Kok, D.-X.A.; Ong-Abdullah, J.; Tan, N.-P.; Lai, K.-S. Transgenic Plants: Gene Constructs, Vector and Transformation Method. In New Visions in Plant Science; IntechOpen: London, UK, 2018.

193. Durvasula, R.V.; Gumbs, A.; Panackal, A.; Kruglov, O.; Aksoy, S.; Merrifield, R.B.; Richards, F.F.; Beard, C.B. Prevention of insect-borne disease: An approach using transgenic symbiotic bacteria. Proc. Natl. Acad. Sci. USA 1997, 94, 3274-3278. [CrossRef]

194. Aksoy, H.M.; Ozman-Sullivan, S.K.; Ocal, H.; Celik, N.; Sullivan, G.T. The effects of Pseudomonas putida biotype B on Tetranychus urticae (Acari: Tetranychidae). Exp. Appl. Acarol. 2008, 46, 223. [CrossRef]

195. Hurwitz, I.; Hillesland, H.; Fieck, A.; Das, P.; Durvasula, R. The paratransgenic sand fly: A platform for control of Leishmania transmission. Parasit. Vectors 2011, 4, 82. [CrossRef]

196. Wang, S.; Ghosh, A.K.; Bongio, N.; Stebbings, K.A.; Lampe, D.J.; Jacobs-Lorena, M. Fighting malaria with engineered symbiotic bacteria from vector mosquitoes. Proc. Natl. Acad. Sci. USA 2012, 109, 12734-12739. [CrossRef] [PubMed]

197. Ramirez, J.L.; Perring, T.M.; Miller, T.A. Fate of a genetically modified bacterium in foregut of glassy-winged sharpshooter (Hemiptera: Cicadellidae). J. Econ. Entomol. 2008, 101, 1519-1525. [CrossRef] [PubMed]

198. Arora, A.K.; Pesko, K.N.; Quintero-Hernández, V.; Possani, L.D.; Miller, T.A.; Durvasula, R.V. A paratransgenic strategy to block transmission of Xylella fastidiosa from the glassy-winged sharpshooter Homalodisca vitripennis. BMC Biotechnol. 2018, 18, 50. [CrossRef]

199. European Food Safety Authority. Workshop on Xylella Fastidiosa: Knowledge Gaps and Research Priorities for the EU; European Food Safety Authority: Parma, Italy, 2016; p. 1039.

200. Saporta, R.; Pedro, T.S.; Gisbert, C. Attempts at grapevine (Vitis vinifera L.) breeding through genetic transformation: The main limiting factors. VITIS J. Grapevine Res. 2016, 55, 173-186. [CrossRef]

201. Sharma, A.; Jones, J.B.; White, F.F. Recent advances in developing disease resistance in plants. F1000Research 2019, 8, 1934. [CrossRef] [PubMed]

202. Gaj, T.; Gersbach, C.A.; Barbas, C.F. ZFN, TALEN, and CRISPR/Cas-based methods for genome engineering. Trends Biotechnol. 2013, 31, 397-405. [CrossRef] [PubMed]

203. Gray, D.J.; Li, Z.T.; Dhekney, S.A. Precision breeding of grapevine (Vitis vinifera L.) for improved traits. Plant Sci. 2014, 228, 3-10. [CrossRef]

204. Hastings, A.; Petrovskii, S.; Morozov, A. Spatial ecology across scales. Biol. Lett. 2011, 7, 163-165. [CrossRef]

205. Fletcher, R.; Fortin, M.-J. Introduction to Spatial Ecology and Its Relevance for Conservation. In Spatial Ecology and Conservation Modeling; Springer: Cham, Switzerland, 2018; pp. 1-13, ISBN 978-3-030-01989-1.

206. Lewis, M.A.; Maini, P.K.; Petrovskii, S.V. Dispersal, Individual Movement and Spatial Ecology; Springer: Berlin/Heidelberg, Germany, 2013; Volume 2071.

207. Santos, M.; Bastos, R.; Vicente, J.; Berger, U.; Soares Filho, B.S.; Rodrigues, H.; Alonso, J.; Guerra, C.; Martins, J.; Honrado, J. 17. Anticipating Invasions and Managing Impacts: A Review of Recent Spatiotemporal Modelling Approaches. In Biological Invasions in Changing Ecosystems; De Gruyter: Berlin, Germany, 2015; pp. 389-410, ISBN 3-11-043866-6.

208. Cunniffe, N.J.; Koskella, B.; Metcalf, C.J.E.; Parnell, S.; Gottwald, T.R.; Gilligan, C.A. Thirteen challenges in modelling plant diseases. Epidemics 2015, 10, 6-10. [CrossRef] [PubMed]

209. Joshi, C.; de Leeuw, J.; van Duren, I.C. Remote sensing and GIS applications for mapping and spatial modelling of invasive species. In Proceedings of the ISPRS 2004: Proceedings of the XXth ISPRS Congress: Geo-Imagery Bridging Continents, Istanbul, Turkey, 12-23 July 2004.

210. Leitão, P.J.; Santos, M.J. Improving models of species ecological niches: A remote sensing overview. Front. Ecol. Evol. 2019, 7, 9. [CrossRef] 
211. Guisan, A.; Zimmermann, N.E. Predictive habitat distribution models in ecology. Ecol. Model. 2000, 135, 147-186. [CrossRef]

212. Vaz, A.S.; Segura, D.A.; Vicente, J.R.; Honrado, J.P. The many roles of remote sensing in invasion science. Front. Ecol. Evol. 2019, 7, 370. [CrossRef]

213. Ellsbury, M.; Clay, S.; Fleischer, S.; Chandler, L.; Schneider, S. Use of GIS/GPS Systems in IPM: Progress and Reality; American Phytopathological Society Press: Saint Paul, MN, USA, 2000; pp. 419-438.

214. Jeger, M.; Bragard, C. The epidemiology of Xylella fastidiosa; A perspective on current knowledge and framework to investigate plant host-vector-pathogen interactions. Phytopathology 2019, 109, 200-209. [CrossRef]

215. Lloyd-Smith, J.O.; Funk, S.; McLean, A.R.; Riley, S.; Wood, J.L. Nine challenges in modelling the emergence of novel pathogens. Epidemics 2015, 10, 35-39. [CrossRef]

216. Stone, C.; Mohammed, C. Application of remote sensing technologies for assessing planted forests damaged by insect pests and fungal pathogens: A review. Curr. For. Rep. 2017, 3, 75-92. [CrossRef]

217. Feil, H.; Purcell, A.H. Temperature-dependent growth and survival of Xylella fastidiosa in vitro and in potted grapevines. Plant Dis. 2001, 85, 1230-1234. [CrossRef]

218. Hoddle, M.S. The potential adventive geographic range of glassy-winged sharpshooter, Homalodisca coagulata and the grape pathogen Xylella fastidiosa: Implications for California and other grape growing regions of the world. Crop Prot. 2004, 23, 691-699. [CrossRef]

219. Bosso, L.; Di Febbraro, M.; Cristinzio, G.; Zoina, A.; Russo, D. Shedding light on the effects of climate change on the potential distribution of Xylella fastidiosa in the Mediterranean basin. Biol. Invasions 2016, 18, 1759-1768. [CrossRef]

220. Godefroid, M.; Cruaud, A.; Streito, J.-C.; Rasplus, J.-Y.; Rossi, J.-P. Xylella fastidiosa: Climate suitability of European continent. Sci. Rep. 2019, 9, 1-10. [CrossRef]

221. Zarco-Tejada, P.; Camino, C.; Beck, P.; Calderon, R.; Hornero, A.; Hernández-Clemente, R.; Kattenborn, T.; Montes-Borrego, M.; Susca, L.; Morelli, M. Previsual symptoms of Xylella fastidiosa infection revealed in spectral plant-trait alterations. Nat. Plants 2018, 4, 432-439. [CrossRef] [PubMed]

222. Ali, M.M.; Bachik, N.A.; Muhadi, N.; Yusof, T.N.T.; Gomes, C. Non-Destructive Techniques of Detecting Plant Diseases: A Review. Physiol. Mol. Plant Pathol. 2019, 108, 101426. [CrossRef]

223. Mahlein, A.-K. Plant disease detection by imaging sensors-parallels and specific demands for precision agriculture and plant phenotyping. Plant Dis. 2016, 100, 241-251. [CrossRef] [PubMed]

224. EFSA. Workshop on Xylella fastidiosa: Knowledge gaps and research priorities for the EU. EFSA Support. Publ. 2016, 13, 1039E.

225. Hornero, A.; Hernández-Clemente, R.; North, P.; Beck, P.; Boscia, D.; Navas-Cortes, J.; Zarco-Tejada, P. Monitoring the incidence of Xylella fastidiosa infection in olive orchards using ground-based evaluations, airborne imaging spectroscopy and Sentinel-2 time series through 3-D radiative transfer modelling. Remote Sens. Environ. 2020, 236, 111480. [CrossRef]

226. Hornero, A.; Hernández-Clemente, R.; Beck, P.S.; Navas-Cortés, J.A.; Zarco-Tejada, P.J. Using Sentinel-2 Imagery to Track Changes Produced by Xylella Fastidiosa in Olive Trees; IEEE: Piscataway Township, NJ, USA, 2018; pp. 9060-9062.

227. Poblete, T.; Camino, C.; Beck, P.; Hornero, A.; Kattenborn, T.; Saponari, M.; Boscia, D.; Navas-Cortes, J.; Zarco-Tejada, P. Detection of Xylella fastidiosa infection symptoms with airborne multispectral and thermal imagery: Assessing bandset reduction performance from hyperspectral analysis. ISPRS J. Photogramm. Remote Sens. 2020, 162, 27-40. [CrossRef]

228. Rey, B.; Aleixos, N.; Cubero, S.; Blasco, J. XF-ROVIM. A field robot to detect olive trees infected by Xylella fastidiosa using proximal sensing. Remote Sens. 2019, 11, 221. [CrossRef]

229. Scortichini, M.; Jianchi, C.; De Caroli, M.; Dalessandro, G.; Pucci, N.; Modesti, V.; L'Aurora, A.; Petriccione, M.; Zampella, L.; Mastrobuoni, F. A zinc, copper and citric acid biocomplex shows promise for control of Xylella fastidiosa subsp. pauca in olive trees in Apulia region (southern Italy). Phytopathol. Mediterr. 2018, 57, 48-72. [CrossRef]

230. Nouri, H.; Beecham, S.; Anderson, S.; Nagler, P. High spatial resolution WorldView-2 imagery for mapping NDVI and its relationship to temporal urban landscape evapotranspiration factors. Remote Sens. 2014, 6, 580-602. [CrossRef] 
231. Rouse, J.; Haas, R.; Schell, J.; Deering, D. Monitoring vegetation systems in the Great Plains with ERTS. NASA Spec. Publ. 1974, 351, 309.

232. Isip, M.; Alberto, R.; Biagtan, A. Exploring vegetation indices adequate in detecting twister disease of onion using Sentinel-2 imagery. Spat. Inf. Res. 2019, 1-7. [CrossRef]

233. Lugonja, P.; Brdar, S.; Simović, I.; Mimić, G.; Palamarchuk, Y.; Sofiev, M.; Šikoparija, B. Integration of in situ and satellite data for top-down mapping of Ambrosia infection level. Remote Sens. Environ. 2019, 235, 111455. [CrossRef]

234. Ballester, C.; Zarco-Tejada, P.; Nicolás, E.; Alarcón, J.; Fereres, E.; Intrigliolo, D.S.; Gonzalez-Dugo, V. Evaluating the performance of xanthophyll, chlorophyll and structure-sensitive spectral indices to detect water stress in five fruit tree species. Precis. Agric. 2018, 19, 178-193. [CrossRef]

235. Calderón, R.; Navas-Cortés, J.A.; Lucena, C.; Zarco-Tejada, P.J. High-resolution airborne hyperspectral and thermal imagery for early detection of Verticillium wilt of olive using fluorescence, temperature and narrow-band spectral indices. Remote Sens. Environ. 2013, 139, 231-245. [CrossRef]

236. Singh, V.; Rana, A.; Bishop, M.; Filippi, A.M.; Bagavathiannan, M.; Nadon, B.; Jackson, S.; Wang, W.; He, A.; Jiang, G. Unmanned aircraft systems for precision weed detection and management: Prospects and challenges. In Advances in Agronomy; Academic Press: Cambridge, MA, USA, 2019. [CrossRef]

237. Mohammed, G.H.; Colombo, R.; Middleton, E.M.; Rascher, U.; van der Tol, C.; Nedbal, L.; Goulas, Y.; Pérez-Priego, O.; Damm, A.; Meroni, M. Remote sensing of solar-induced chlorophyll fluorescence (SIF) in vegetation: 50 years of progress. Remote Sens. Environ. 2019, 231, 111177. [CrossRef]

238. European Space Agency. Report for Mission Selection: FLEX; European Space Agency: Paris, France, 2015; p. 197.

239. Middleton, E.M.; Rascher, U.; Huemmrich, K.F.; Cook, B.D.; Noormets, A.; Schickling, A.; Pinto, F.; Alonso, L.; Damm, A.; Guanter, L. The 2013 FLEX-US airborne campaign at the parker tract loblolly pine plantation in North Carolina, USA. Remote Sens. 2017, 9, 612. [CrossRef]

240. Martinetti, D.; Soubeyrand, S. Identifying lookouts for epidemio-surveillance: Application to the emergence of Xylella fastidiosa in France. Phytopathology 2019, 109, 265-276. [CrossRef]

241. Poliakoff, F.; Legendre, B.; Juteau, V.; Molusson, D.; Dintheer, A.; Sainte-Luce, A.; Dousset, C.; Audusseau, A.; Paillard, S.; Cunty, A.; et al. Current Situation in France Regarding Xylella fastidiosa: Recent Developments and Validation of Detection Method on Plants and Vector Philaenus spumarius. Available online: https: //figshare.com/articles/Current_situation_in_France_regarding_Xylella_fastidiosa_recent_developments_ and_validation_of_detection_method_on_plants_and_vector_Philaenus_spumarius_/11704422 (accessed on 24 January 2020).

242. EFSA. Update of the Xylella spp. host plant database. EFSA J. 2018, 16, e05408. [CrossRef]

243. Bosso, L.; Russo, D.; Di Febbraro, M.; Cristinzio, G.; Zoina, A. Potential distribution of Xylella fastidiosa in Italy: A maximum entropy model. Phytopathol. Mediterr. 2016, 62-72. [CrossRef]

244. Cornara, D.; Bosco, D.; Fereres, A. Philaenus spumarius: When an old acquaintance becomes a new threat to European agriculture. J. Pest Sci. 2018, 91, 957-972. [CrossRef]

245. Dongiovanni, C.; Cavalieri, V.; Bodino, N.; Tauro, D.; Di Carolo, M.; Fumarola, G.; Altamura, G.; Lasorella, C.; Bosco, D. Plant selection and population trend of spittlebug immatures (Hemiptera: Aphrophoridae) in olive groves of the Apulia Region of Italy. J. Econ. Entomol. 2019, 112, 67-74. [CrossRef] [PubMed]

246. Strona, G.; Carstens, C.J.; Beck, P.S. Network analysis reveals why Xylella fastidiosa will persist in Europe. Sci. Rep. 2017, 7, 1-8. [CrossRef] [PubMed]

247. Groom, Q.J.; Desmet, P.; Vanderhoeven, S.; Adriaens, T. The importance of open data for invasive alien species research, policy and management. Manag. Biol. Invasions 2015, 6, 119-125. [CrossRef]

248. Latini, A.; Foxi, C.; Borfecchia, F.; Lentini, A.; De Cecco, L.; Iantosca, D.; Serafini, M.; Laneri, U.; Citterio, M.; Campiotti, A. Tacking the vector of Xylella fastidiosa: Geo-statistical analysis of long-term field observations on host plants influencing the distribution of Phylaenus spumarius nymphs. Environ. Sci. Pollut. Res. 2019, 26, 6503-6516. [CrossRef]

249. Santoiemma, G.; Tamburini, G.; Sanna, F.; Mori, N.; Marini, L. Landscape composition predicts the distribution of Philaenus spumarius, vector of Xylella fastidiosa, in olive groves. J. Pest Sci. 2019, 92, 1101-1109. [CrossRef]

250. Di Serio, F.; Bodino, N.; Cavalieri, V.; Demichelis, S.; Di Carolo, M.; Dongiovanni, C.; Fumarola, G.; Gilioli, G.; Guerrieri, E.; Picciotti, U. Collection of Data and Information on Biology and Control of Vectors of Xylella fastidiosa. EFSA Supporting Publ. 2019, 16. [CrossRef] 
251. Morente, M.; Cornara, D.; Plaza, M.; Durán, J.M.; Capiscol, C.; Trillo, R.; Ruiz, M.; Ruz, C.; Sanjuan, S.; Pereira, J.A.; et al. Distribution and relative abundance of insect vectors of Xylella fastidiosa in olive groves of the Iberian peninsula. Insects 2018, 9, 175. [CrossRef]

252. Maggiore, G.; Semeraro, T.; Aretano, R.; De Bellis, L.; Luvisi, A. GIS analysis of land-use change in threatened landscapes by Xylella fastidiosa. Sustainability 2019, 11, 253. [CrossRef]

253. Semeraro, T.; Gatto, E.; Buccolieri, R.; Vergine, M.; Gao, Z.; De Bellis, L.; Luvisi, A. Changes in Olive Urban Forests Infected by Xylella fastidiosa: Impact on Microclimate and Social Health. Int. J. Environ. Res. Public Health 2019, 16, 2642. [CrossRef]

254. De Angelis, D.L.; Yurek, S. Spatially explicit modeling in ecology: A review. Ecosystems 2017, 20, $284-300$. [CrossRef]

255. Austin, M. Species distribution models and ecological theory: A critical assessment and some possible new approaches. Ecol. Model. 2007, 200, 1-19. [CrossRef]

256. Hernández, O.G.; García, L.V. La dimensión geográfica de las invasiones biológicas en el Antropoceno: El caso de Xylella fastidiosa. Bol. Asoc. Geógrafos Esp. 2019. [CrossRef]

257. Hernández, O.G.; García, L.V. Incidencia de Xylella fastidiosa en las Islas Baleares y distribución potencial en la península ibérica. Investig. Geográficas Esp 2018, 55-72. [CrossRef]

258. Godefroid, M.; Cruaud, A.; Streito, J.-C.; Rasplus, J.-Y.; Rossi, J.-P. Climate change and the potential distribution of Xylella fastidiosa in Europe. BioRxiv 2018, 289876. [CrossRef]

259. Hao, T.; Elith, J.; Guillera-Arroita, G.; Lahoz-Monfort, J.J. A review of evidence about use and performance of species distribution modelling ensembles like BIOMOD. Divers. Distrib. 2019, 25, 839-852. [CrossRef]

260. Lieth, J.; Meyer, M.; Yeo, K.-H.; Kirkpatrick, B. Modeling cold curing of Pierce's disease in Vitis vinifera 'Pinot Noir'and 'Cabernet sauvignon'grapevines in California. Phytopathology 2011, 101, 1492-1500. [CrossRef]

261. Broadmeadow, S.; Watts, K.; Quine, C.; Mitchell, R. Risk Mapping of the Likelihood and Impact of a Xylella Fastidiosa Outbreak in Scotland; Plant Health Centre: Dundee, UK, 2019.

262. Chapman, D.S.; White, S.M.; Hooftman, D.A.; Bullock, J.M. Inventory and Review of Quantitative Models for Spread of Plant Pests for Use in Pest Risk Assessment for the EU Territory; Wiley Online Library: Hoboken, NJ, USA, 2015.

263. White, S.M.; Bullock, J.M.; Hooftman, D.A.; Chapman, D.S. Modelling the spread and control of Xylella fastidiosa in the early stages of invasion in Apulia, Italy. Biol. Invasions 2017, 19, 1825-1837. [CrossRef]

264. Abboud, C.; Bonnefon, O.; Parent, E.; Soubeyrand, S. Dating and localizing an invasion from post-introduction data and a coupled reaction-diffusion-absorption model. J. Math. Biol. 2019, 79, 765-789. [CrossRef]

265. Soubeyrand, S.; de Jerphanion, P.; Martin, O.; Saussac, M.; Manceau, C.; Hendrikx, P.; Lannou, C. Inferring pathogen dynamics from temporal count data: The emergence of Xylella fastidiosa in France is probably not recent. New Phytol. 2018, 219, 824-836. [CrossRef]

266. White, S.; Bullock, J.; Cavers, S.; Chapman, D. Using Modelling to Investigate the Effectiveness of National Surveillance Monitoring Aimed at Detecting a Xylella Fastidiosa Outbreak in Scotland; Plant Health Centre: Dundee, UK, 2019.

267. Almeida, R.; De La Fuente, L.; Koebnik, R.; Lopes, J.R.S.; Parnell, S.; Scherm, H. Addressing the new global threat of Xylella fastidiosa. Phytopathology 2019, 109, 172-174. [CrossRef] [PubMed]

268. Martelli, G.P. The current status of the quick decline syndrome of olive in southern Italy. Phytoparasitica 2016, 44, 1-10. [CrossRef]

269. Sicard, A.; Zeilinger, A.R.; Vanhove, M.; Schartel, T.E.; Beal, D.J.; Daugherty, M.P.; Almeida, R.P. Xylella fastidiosa: Insights into an emerging plant pathogen. Annu. Rev. Phytopathol. 2018, 56, 181-202. [CrossRef]

270. Elad, Y.; Pertot, I. Climate change impacts on plant pathogens and plant diseases. J. Crop Improv. 2014, 28, 99-139. [CrossRef]

271. Trebicki, P.; Finlay, K. Pests and diseases under climate change; its threat to food security. Food Secur. Clim. Chang. 2019, 229-249. [CrossRef]

272. Trębicki, P.; Vandegeer, R.K.; Bosque-Pérez, N.A.; Powell, K.S.; Dader, B.; Freeman, A.J.; Yen, A.L.; Fitzgerald, G.J.; Luck, J.E. Virus infection mediates the effects of elevated CO 2 on plants and vectors. Sci. Rep. 2016, 6, 22785. [CrossRef] [PubMed]

273. Kudela, V. Potential impact of climate change on geographic distribution of plant pathogenic bacteria in Central Europe. Plant Prot. Sci. 2009, 45. [CrossRef] 
274. Hegerl, G.C.; Zwiers, F.W.; Stott, P.A.; Kharin, V.V. Detectability of anthropogenic changes in annual temperature and precipitation extremes. J. Clim. 2004, 17, 3683-3700. [CrossRef]

275. Kosmas, C.; Danalatos, N. Climate change, desertification and the Mediterranean region. In Soil Responses to Climate Change; Springer: Berlin/Heidelberg, Germany, 1994; pp. 25-38.

276. Robinson, E.A.; Ryan, G.D.; Newman, J.A. A meta-analytical review of the effects of elevated $\mathrm{CO}_{2}$ on plant-arthropod interactions highlights the importance of interacting environmental and biological variables. New Phytol. 2012, 194, 321-336. [CrossRef]

277. Hughes, L.; Bazzaz, F.A. Effects of elevated $\mathrm{CO}_{2}$ on five plant-aphid interactions. Entomol. Exp. Appl. 2001, 99, 87-96. [CrossRef]

278. Xie,H.; Zhao, L.; Wang, W.; Wang,Z.; Ni, X.; Cai, W.; He, K. Changes in life history parameters of Rhopalosiphum maidis (Homoptera: Aphididae) under four different elevated temperature and $\mathrm{CO}_{2}$ combinations. J. Econ. Entomol. 2014, 107, 1411-1418. [CrossRef] [PubMed]

279. Peñalver-Cruz, A.; Garzo, E.; Prieto-Ruiz, I.; Díaz-Carro, M.; Winters, A.; Moreno, A.; Fereres, A. Feeding behavior, life history, and virus transmission ability of Bemisia tabaci Mediterranean species (Hemiptera: Aleyrodidae) under elevated $\mathrm{CO}_{2}$. Insect Sci. 2019, 27, 558-570. [CrossRef] [PubMed]

280. Li, Z.; Liu, T.; Xiao, N.; Li, J.; Chen, F. Effects of elevated $\mathrm{CO}_{2}$ on the interspecific competition between two sympatric species of Aphis gossypii and Bemisia tabaci fed on transgenic Bt cotton. Insect Sci. 2011, 18, 426-434. [CrossRef]

281. Klaiber, J.; Najar-Rodriguez, A.J.; Dialer, E.; Dorn, S. Elevated carbon dioxide impairs the performance of a specialized parasitoid of an aphid host feeding on Brassica plants. Biol. Control 2013, 66, 49-55. [CrossRef]

282. Overgaard, J.; Kearney, M.R.; Hoffmann, A.A. Sensitivity to thermal extremes in A ustralian Drosophila implies similar impacts of climate change on the distribution of widespread and tropical species. Glob. Chang. Biol. 2014, 20, 1738-1750. [CrossRef] [PubMed]

283. Wiens, J.J.; Graham, C.H. Niche conservatism: Integrating evolution, ecology, and conservation biology. Annu. Rev. Ecol. Evol. Syst. 2005, 36, 519-539. [CrossRef]

284. Gerson, U.; Weintraub, P.G. Mites (Acari) as a factor in greenhouse management. Annu. Rev. Entomol. 2012, 57, 229-247. [CrossRef]

285. Cao, L.-J.; Gao, Y.-F.; Gong, Y.-J.; Chen, J.-C.; Chen, M.; Hoffmann, A.; Wei, S.-J. Population analysis reveals genetic structure of an invasive agricultural thrips pest related to invasion of greenhouses and suitable climatic space. Evol. Appl. 2019, 12, 1868-1880. [CrossRef]

286. Broennimann, O.; Treier, U.A.; Müller-Schärer, H.; Thuiller, W.; Peterson, A.; Guisan, A. Evidence of climatic niche shift during biological invasion. Ecol. Lett. 2007, 10, 701-709. [CrossRef]

287. Gholam, Z.; Sadeghi, A. Management strategies for western flower thrips in vegetable greenhouses in Iran: A review. Plant Prot. Sci. 2016, 52, 87-98. [CrossRef]

288. Ricciardi, A.; Blackburn, T.M.; Carlton, J.T.; Dick, J.T.A.; Hulme, P.E.; Iacarella, J.C.; Jeschke, J.M.; Liebhold, A.M.; Lockwood, J.L.; MacIsaac, H.J.; et al. Invasion Science: A Horizon Scan of Emerging Challenges and Opportunities. Trends Ecol. Evol. 2017, 32, 464-474. [CrossRef] [PubMed]

289. Bullock, J.M.; Bonte, D.; Pufal, G.; da Silva Carvalho, C.; Chapman, D.S.; García, C.; García, D.; Matthysen, E.; Delgado, M.M. Human-mediated dispersal and the rewiring of spatial networks. Trends Ecol. Evol. 2018, 33, 958-970. [CrossRef] [PubMed]

290. Trębicki, P.; Dáder, B.; Vassiliadis, S.; Fereres, A. Insect-plant-pathogen interactions as shaped by future climate: Effects on biology, distribution, and implications for agriculture. Insect Sci. 2017, 24, 975-989. [CrossRef] [PubMed]

291. Toft, C.; Andersson, S.G. Evolutionary microbial genomics: Insights into bacterial host adaptation. Nat. Rev. Genet. 2010, 11, 465-475. [CrossRef] [PubMed]

292. Esteves, M.B.; Kleina, H.T.; Sales, T.d.M.; Oliveira, T.P.; de Lara, I.A.R.; Almeida, R.P.P.; Coletta-Filho, H.D.; Lopes, J.R.S. Transmission Efficiency of Xylella fastidiosa subsp. pauca Sequence Types by Sharpshooter Vectors after In Vitro Acquisition. Phytopathology 2018, 109, 286-293. [CrossRef] [PubMed]

293. Salzberg, S.L. Next-generation genome annotation: We still struggle to get it right. Genome Biol. 2019, $20,92$. [CrossRef]

294. Kuśmirek, W.; Nowak, R. De novo assembly of bacterial genomes with repetitive DNA regions by dnaasm application. BMC Bioinform. 2018, 19, 273. [CrossRef] 
295. Ouyang, S.; Park, G.; Atamian, H.S.; Han, C.S.; Stajich, J.E.; Kaloshian, I.; Borkovich, K.A. MicroRNAs Suppress NB Domain Genes in Tomato That Confer Resistance to Fusarium oxysporum. PLoS Pathog. 2014, 10. [CrossRef]

296. Benes, V.; Castoldi, M. Expression profiling of microRNA using real-time quantitative PCR, how to use it and what is available. Methods 2010, 50, 244-249. [CrossRef]

297. Depledge, D.P.; Srinivas, K.P.; Sadaoka, T.; Bready, D.; Mori, Y.; Placantonakis, D.G.; Mohr, I.; Wilson, A.C. Direct RNA sequencing on nanopore arrays redefines the transcriptional complexity of a viral pathogen. Nat. Commun. 2019, 10, 754. [CrossRef]

298. Quijada, N.M.; Rodríguez-Lázaro, D.; Eiros, J.M.; Hernández, M. TORMES: An automated pipeline for whole bacterial genome analysis. Bioinformatics 2019, 35, 4207-4212. [CrossRef]

299. Genovesi, P.; Shine, C. European Strategy on Invasive Alien Species: Convention on the Conservation of European Wildlife and Habitats (Bern Convention); Council of Europe: Strasbourg, France, 2004; ISBN 92-871-5488-0.

300. Gallien, L.; Münkemüller, T.; Albert, C.H.; Boulangeat, I.; Thuiller, W. Predicting potential distributions of invasive species: Where to go from here? Divers. Distrib. 2010, 16, 331-342. [CrossRef]

301. Huang, C.; Asner, G.P. Applications of remote sensing to alien invasive plant studies. Sensors 2009, 9, 4869-4889. [CrossRef] [PubMed]

302. Gualano, S.; Tarantino, E.; Santoro, F.; Valentini, F.; Dongiovanni, N.; D’Onghia, A.M. Analisi Assistita da Immagini Aeree ad Elevata Risoluzione Geometrica per il Riconoscimento del Complesso del Disseccamento Rapido dell'Olivo Associato al Batterio Xylella fastidiosa in Puglia. Available online: http://atti.asita.it/ ASITA2014/Pdf/097.pdf (accessed on 28 May 2020).

303. D'onghia, A.M. CIHEAM/IAMB innovative tools for early surveillance and detection of Xylella fastidiosa. In Xylella Fastidiosa \& the Olive Quick Decline Syndrome (OQDS) A Serious Worldwide Challenge for the Safeguard of Olive Trees; D’Onghia, A.M., Brunel, S., Valentini, F., Eds.; CIHEAM: Paris, France, 2017; Volume 172.

304. D'onghia, A.M.; Brunel, S.; Valentini, F. Xylella Fastidiosa \& the Olive Quick Decline Syndrome (OQDS) A Serious Worldwide Challenge for the Safeguard of Olive Trees; CIHEAM: Paris, France, 2017; ISBN 978-2-85352-570-1.

305. Gippet, J.M.; Liebhold, A.M.; Fenn-Moltu, G.; Bertelsmeier, C. Human-mediated dispersal in insects. Curr. Opin. Insect Sci. 2019, 35, 96-102. [CrossRef]

306. Almeida, R.P.P. Emerging plant disease epidemics: Biological research is key but not enough. PLoS Biol. 2018, 16, e2007020. [CrossRef] 